Article

\title{
Trend Analysis of Rainfall Time Series in Shanxi Province, Northern China (1957-2019)
}

\author{
Feng Gao ${ }^{1}$, Yunpeng Wang ${ }^{2} \mathbb{D}$, Xiaoling Chen ${ }^{3, *}$ and Wenfu Yang ${ }^{4,5}$ \\ 1 School of Resources and Environment, Shanxi University of Finance and Economics, Taiyuan 030006, China; \\ gaofeng0204@sxufe.edu.cn \\ 2 Guangzhou Institute of Geochemistry, Chinese Academy of Sciences, Guangzhou 510640, China; \\ wangyp@gig.ac.cn \\ 3 State Key Laboratory of Information Engineering in Surveying, Mapping and Remote Sensing, \\ Wuhan University, Wuhan 430079, China \\ 4 School of Land Science and Technology, China University of Geosciences, Beijing 100083, China; \\ wcyywf@163.com \\ 5 Shanxi Key Laboratory of Resources, Environment and Disaster Monitoring, Shanxi Coal Geology \\ Geophysical Surveying Exploration Institute, Jinzhong 030600, China \\ * Correspondence: xiaoling_chen@whu.edu.cn
}

Received: 19 July 2020; Accepted: 19 August 2020; Published: 20 August 2020

\begin{abstract}
Changes in rainfall play an important role in agricultural production, water supply and management, and social and economic development in arid and semi-arid regions. The objective of this study was to examine the trend of rainfall series from 18 meteorological stations for monthly, seasonal, and annual scales in Shanxi province over the period 1957-2019. The Mann-Kendall (MK) test, Spearman's Rho (SR) test, and the Revised Mann-Kendall (RMK) test were used to identify the trends. Sen's slope estimator (SSE) was used to estimate the magnitude of the rainfall trend. An autocorrelation function (ACF) plot was used to examine the autocorrelation coefficients at various lags in order to improve the trend analysis by the application of the RMK test. The results indicate remarkable differences with positive and negative trends (significant or non-significant) depending on stations. The largest number of stations showing decreasing trends occurred in March, with 10 out of 18 stations at the $10 \%, 5 \%$, and $1 \%$ levels. Wutai Shan station has strong negative trends in January, March, April, November, and December at the level of 1\%. In addition, Wutai Shan station also experienced a significant decreasing trend over four seasons at a significance level of $1 \%$ and $10 \%$. On the annual scale, there was no significant trend detected by the three identification methods for most stations. MK and SR tests have similar power for detecting monotonic trends in rainfall time series data. Although similar results were obtained by the MK/SR and RMK tests in this study, in some cases, unreasonable trends may be provided by the RMK test. The findings of this study could benefit agricultural production activities, water supply and management, drought monitoring, and socioeconomic development in Shanxi province in the future.
\end{abstract}

Keywords: trend analysis; nonparametric trend identification; Mann-Kendall test; Spearman's Rho test; revised Mann-Kendall test

\section{Introduction}

Rainfall is one of the most important climate elements that can directly affect the availability of water resources, can be used for diagnosing climate change under the background of global warming [1,2], and influence agricultural production activities and the ecohydrological environment [3-5]. Relevant studies have shown that water cycle modification, with rainfall being a key point in the process, is considered the most noticeable consequence of global atmospheric warming [6,7]. In addition, 
the spatial and temporal distribution of runoff, soil moisture, and groundwater reserves can be influenced by a change of rainfall distribution and the frequency of droughts and floods can also be altered [8]. Therefore, variations and trends around rainfall should be investigated and analyzed for planning and managing of water resources, and also for the purpose of designing suitable plans to cope with floods and drought conditions [3].

In recent years, many studies related to the trends and variability in precipitation under global warming have investigated different regions, such as India [4,5,9-13], the Mediterranean [14-18], Ethiopia [19], China [1,2,20-25], the Netherlands [26], South Korea [27], Brazil [28], Germany [29], and West Africa [30]. Although various studies on rainfall variation and trend analysis have been investigated in western [31,32], eastern [24], southern [33], north-west [34], south-east [2], and south-west China [23], little investigation has been carried out in the northern regions (e.g., Shanxi province, China). Meanwhile, relevant studies have suggested that various change patterns can be detected for different regions within a country [26,33,35,36]. Liu et al. [37] investigated the spatial and temporal patterns of trends of the precipitation in the Yellow River Basin (YRB) from 81 meteorological stations during the period 1961-2006. They found that most of the precipitation stations showed a downward trend, while only two meteorological stations displayed upward trends. Zhang et al. [33] analyzed the spatial and temporal changes of precipitation structure in the Pearl River Basin based on daily observed precipitation data at 42 rain gauging stations from 1960 to 2005. Decreasing trends in precipitation were found mainly in the middle and upper Pearl River Basin. However, a decreasing number of rainy days was identified almost over the entire basin. Wang et al. [24] analyzed the trend on annual and seasonal rainfall in the Yangtze River Delta, eastern China, using observed data from 14 rain gauging stations during 1961-2016, and found statistically significant upward trends in annual rainfall at all stations. Summer and winter presented increasing trends, while spring and autumn showed decreasing trends. In addition, precipitation extremes under global warming have also been investigated in various regions to better understand the rainfall regime changes due to climate change. Li et al. [38] applied an iterative-based Mann-Kendall trend test and examined the long-term trends in precipitation extremes (1980-2013). Frequency and intensity of precipitation in terms of inter-annual variability was also investigated. They found the frequency and intensity of precipitation extremes in Singapore showed a significant increasing trend. Three potential factors-El Niño-Southern Oscillation (ENSO), global mean temperature, and local temperature-are significantly correlated with precipitation extremes. Chow et al. [39] investigated the impacts of changing frequencies and intensities of extreme weather events on urban settlement, and concluded that the warm environment observed in Singapore and surface dryness have been more intense in recent periods. Change of occurrence of time and length of the extreme precipitation period, as well as influencing factors, were investigated by Guo et al. [40]. They found atmospheric circulation patterns have significant effects on the occurrence time and length of the extreme precipitation period. Changes of extreme precipitation induced by the global mean temperature and ENSO have been investigated by several researchers [41-44]. Meanwhile, the impacts of ENSO on regional rainfall have been examined around the world. Philippon et al. [45] analyzed the relationship between ENSO and South Africa austral winter rainfall using a long-term daily rainfall database, and found seasonal rainfall (May, June, and July) had a positive correlation with the Niño 3.4 index. Räsänen and Kummu [46] examined the impact of ENSO on large inter-annual variations between large floods and severe droughts. The results showed that both precipitation and discharge are influenced by ENSO. The precipitation and discharge decreased in El Niño years, while they increased in La Niña years. In order to understand the nature of the rainfall variations under climate change, more studies should be conducted for different geographical regions [11].

The non-parametric Mann-Kendall (MK) test and Spearman's Rho (SR) test are commonly employed to detect monotonic trends in time series of climatic and hydrologic variables. However, the results of the test may contain error if significant autocorrelation exists in the data series. To avoid this problem, a Revised Mann-Kendall test has been proposed by Hamed and Rao [47] using a variance correction method to eliminate the effect of autocorrelation in the time series data. The magnitudes of 
trend slope for monthly, seasonal, and annual rainfall series in many study areas have been estimated by using Sen's slope estimator $[4,8,13,20]$.

Shanxi is a province with serious soil erosion concerns in northern China, and is also a fragile ecological zones which is sensitive to global climate change [48]. The per capita water resources in Shanxi province is only $456 \mathrm{~m}^{3}$, accounting for $1 / 5$ th of the national average and far below the severe water shortage limit of $1000 \mathrm{~m}^{3}$. The average amount of water used by cultivated land is $3255 \mathrm{~m}^{3} / \mathrm{hm}^{2}$, which is only $1 / 9$ th of the national average. Therefore, changes of rainfall in Shanxi province will have a negative effect on the water supply, agricultural irrigation, ecological systems, and socioeconomic development [24,25].

Most studies of rainfall changes in Shanxi province have been concerned with annual rainfall; little research has been undertaken on annual, seasonal, and monthly time series data using all available meteorological stations [48,49]. This study attempts to apply the Mann-Kendall (MK) test, Spearman's Rho (SR) test, Revised Mann-Kendall (RMK) test and Sen's slope estimator (SSE) to detect trends of rainfall on the annual, seasonal, and monthly scales in Shanxi province, based on the latest high-quality observed data from 1957 to 2019. Therefore, the main objectives of this study were to: (1) analyze temporal trend in annual, seasonal, and monthly rainfall time series data using the MK/SR and RMK tests; (2) investigate the magnitude of trend line in annual, seasonal, and monthly time series data using SSE; and (3) compare the difference between MK/SR and RMK in detecting the trends of long-term time series rainfall data.

\section{Materials and Methods}

\subsection{Study Area and Data Availability}

Shanxi province is located in the middle of China and lies in the east of the Loess Plateau, which is a typical semi-arid region in northern China. It lies between $34^{\circ} 34^{\prime} \mathrm{N}$ to $40^{\circ} 43^{\prime} \mathrm{N}$ latitude and $110^{\circ} 14^{\prime} \mathrm{E}$ to $114^{\circ} 33^{\prime} \mathrm{E}$ longitude (Figure 1) and covers an area of $156,700 \mathrm{~km}^{2}$. Shanxi has a temperate continental monsoon climate. High temperatures and rainy days occur across the summer, while low temperatures and dry weather conditions characterize the winter. The average annual temperature ranges from $3{ }^{\circ} \mathrm{C}$ to $14{ }^{\circ} \mathrm{C}$. The mean annual precipitation is between $350 \mathrm{~mm}$ and $700 \mathrm{~mm}$, with $60 \%$ of it concentrated in June, July, and August, and the amount of precipitation is greatly affected by the topography. The average elevation of Shanxi province is $1000 \mathrm{~m}$, with the highest elevation being $3059 \mathrm{~m}$ and the lowest elevation being $205 \mathrm{~m}$ (Figure 1). There are four seasons according to the climatology, namely spring (March to May), summer (June to August), autumn (September to November), and winter (December to the following February). The location of Shanxi province in China, along with the topography and spatial distribution of meteorological stations, is shown in Figure 1.

Monthly rainfall data of 18 meteorological stations of Shanxi province for 63 years (1957-2019), except for Changzhi station (47 years), were collected from the China Meteorological Data Network. Quality checks and homogeneity were carried out and controlled before these data were released. The monthly rainfall data for the 18 meteorological stations were aggregated to total rainfall at seasonal and annual scale for trend analysis. The geographical location and elevation information of the meteorological stations and the corresponding length of the rainfall record is provided in Table 1. 


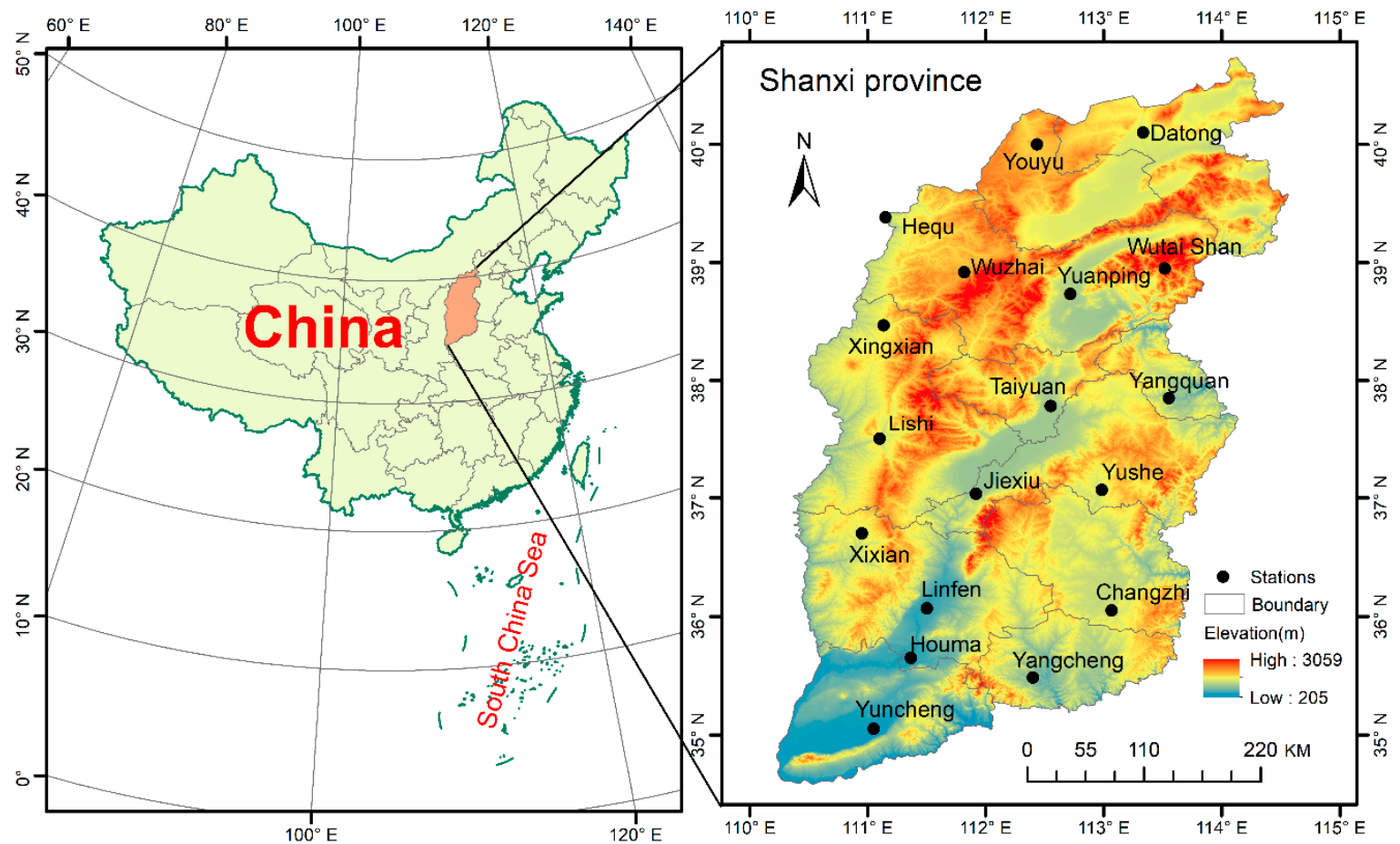

Figure 1. Location map of the study area and the topography and meteorological stations marked as black dot.

Table 1. Description of 18 meteorological stations in the study area considered for analysis.

\begin{tabular}{cccccc}
\hline Station ID & Station & Latitude & Longitude & Elevation $(\mathbf{m})$ & Record Period \\
\hline 53478 & Youyu & $40^{\circ} 00^{\prime}$ & $112^{\circ} 27^{\prime}$ & 1345.8 & $1957-2019$ \\
53487 & Datong & $40^{\circ} 06^{\prime}$ & $113^{\circ} 20^{\prime}$ & 1067.2 & $1957-2019$ \\
53564 & Hequ & $39^{\circ} 23^{\prime}$ & $111^{\circ} 09^{\prime}$ & 861.5 & $1957-2019$ \\
53588 & Wutai Shan & $38^{\circ} 57^{\prime}$ & $113^{\circ} 31^{\prime}$ & 2208.3 & $1957-2019$ \\
53663 & Wuzhai & $38^{\circ} 55^{\prime}$ & $111^{\circ} 49^{\prime}$ & 1401 & $1957-2019$ \\
53664 & Xingxian & $38^{\circ} 28^{\prime}$ & $111^{\circ} 08^{\prime}$ & 1012.6 & $1957-2019$ \\
53673 & Yuanping & $38^{\circ} 44^{\prime}$ & $112^{\circ} 43^{\prime}$ & 828.2 & $1957-2019$ \\
53764 & Lishi & $37^{\circ} 30^{\prime}$ & $111^{\circ} 06^{\prime}$ & 950.8 & $1957-2019$ \\
53772 & Taiyuan & $37^{\circ} 47^{\prime}$ & $112^{\circ} 33^{\prime}$ & 778.3 & $1957-2019$ \\
53782 & Yangquan & $37^{\circ} 51^{\prime}$ & $113^{\circ} 33^{\prime}$ & 741.9 & $1957-2019$ \\
53787 & Yushe & $37^{\circ} 04^{\prime}$ & $112^{\circ} 59^{\prime}$ & 1041.4 & $1957-2019$ \\
53853 & Xixian & $36^{\circ} 42^{\prime}$ & $110^{\circ} 57^{\prime}$ & 1052.7 & $1957-2019$ \\
53863 & Jiexiu & $37^{\circ} 02^{\prime}$ & $111^{\circ} 55^{\prime}$ & 743.9 & $1957-2019$ \\
53868 & Linfen & $36^{\circ} 04^{\prime}$ & $111^{\circ} 30^{\prime}$ & 449.5 & $1957-2019$ \\
53882 & Changzhi & $36^{\circ} 03^{\prime}$ & $113^{\circ} 04^{\prime}$ & 991.8 & $1973-2019$ \\
53959 & Yuncheng & $35^{\circ} 03^{\prime}$ & $111^{\circ} 03^{\prime}$ & 365 & $1957-2019$ \\
53963 & Houma & $35^{\circ} 39^{\prime}$ & $111^{\circ} 22^{\prime}$ & 433.8 & $1957-2019$ \\
53975 & Yangcheng & $35^{\circ} 29^{\prime}$ & $112^{\circ} 24^{\prime}$ & 659.5 & $1957-2019$ \\
\hline
\end{tabular}

\subsection{Methodology}

\subsubsection{The Mann-Kendall Test}

The Mann-Kendall test (MK), proposed by Mann [50] and Kendall [51], is a non-parametric test that is widely used to detect monotonic trends for time series of hydrology, meteorological, and environment data. A non-parametric test does not require data to be normally distributed and is flexible to outliers in the time series [52]. The test assumes a null hypothesis, H0, of no trend. The alternative hypothesis, H1, is that a monotonic trend is identified (increasing or decreasing). 
For a given time series $X_{i}=x_{1}, x_{2}, \ldots, x_{n}$, the Mann-Kendall test statistic $S$ is calculated as

$$
S=\sum_{i=1}^{n-1} \sum_{j=i+1}^{n} \operatorname{sign}\left(x_{j}-x_{i}\right)
$$

where $n$ is the number of data points; $x_{i}$ and $x_{j}$ are the data values in time series $i$ and $j(j>i)$, respectively; and $\operatorname{sign}\left(x_{j}-x_{i}\right)$ is the sign function as

$$
\operatorname{sign}\left(x_{i}-x_{j}\right)=\left\{\begin{array}{ccc}
-1 & \text { if } & \left(x_{j}-x_{i}\right)<0 \\
0 & \text { if } & \left(x_{j}-x_{i}\right)=0 \\
1 & \text { if } & \left(x_{j}-x_{i}\right)>0
\end{array}\right.
$$

The variance is computed as

$$
\operatorname{Var}(S)=\frac{n(n-1)(2 n+5)-\sum_{k=1}^{m} t_{k}(k)(k-1)(2 k+5)}{18}
$$

where $n$ is the number of data points; $m$ is the number of tied groups; and $t_{k}$ denotes the number of extent $k$. Standardized test statistics, $Z$, are used to detect a significant trend, and expressed as:

$$
Z= \begin{cases}\frac{S-1}{\sqrt{\operatorname{Var}(S)}} & \text { if } S>0 \\ 0 & \text { if } S=0 \\ \frac{S-1}{\sqrt{\operatorname{Var}(S)}} & \text { if } S<0\end{cases}
$$

The monotonic trend can be identified by the values of $Z$. Negative values of $Z$ indicate downward trends while positive values of $Z$ indicate upward trends. The statistically significant trend test is undertaken at the specific $\alpha$ significance level. When $|Z|>Z_{1-\frac{\alpha}{2}}$, the null hypothesis is rejected, and a significant trend exists in the time series. Significance levels of $\alpha=0.05$ and $\alpha=0.01$ were used in this study. At the $5 \%$ significance level, the null hypothesis of no trend is rejected if $|Z|>1.96$, and it is rejected if $|Z|>2.33$ at the $1 \%$ significance level [3,4,53].

\subsubsection{The Spearman's Rho Test}

The Spearman's Rho (SR) test [54] is another widely used non-parametric test for detecting monotonic trends in time series data. Yue et al. [55] investigated the power of the MK and SR tests for detecting monotonic trends in hydrological series. The results indicated that these two non-parametric tests have similar power in detecting a trend. For a given time series $X_{i}=x_{1}, x_{2}, \ldots, x_{n}$, the Spearman's correlation coefficient $r_{S R C}$ is given as

$$
r_{S R C}=1-\left\{\frac{6 \sum_{i=1}^{n}\left[d_{i}\right]^{2}}{n\left(n^{2}-1\right)}\right\}
$$

where $d_{i}=\left(R X_{i}-R Y_{i}\right) . R X_{i}$ is the rank of the variable $X_{i} ; R Y$ is the chronological order of observations and $i=1,2, \ldots, n$ in series of size $n$. The test statistic $t_{S R C}$ is given by Equation (6).

$$
t_{S R C}=r_{S R C} \sqrt{\frac{(n-2)}{1-r^{2} S R C}}
$$

The test statistic $t_{S R C}$ follows a t-distribution with degree of freedom $v$ and significance level $\alpha$ [43]. The null hypothesis of no trend is rejected when $\left|t_{S R C}\right|>t_{v, 1-(\sigma / 2)}$. 


\subsubsection{Sen's Slope Estimator}

The Sen's slope estimator [56], a robust non-parametric method, is used to estimate the magnitude of the trend slope. For a given time series $X_{i}=x_{1}, x_{2}, \ldots, x_{n}$, with $\mathrm{N}$ pairs of data, the slope is calculated as Sen's [57]

$$
f(t)=Q t+B
$$

where $Q$ indicates the slope, while $B$ is a constant. The slope of $Q_{i}$ in the sample of $\mathrm{N}$ pairs of data is calculated:

$$
Q_{i}=\frac{x_{j}-x_{k}}{j-k}
$$

where $x_{j}$ and $x_{k}$ are the values of data pairs at times $j$ and $k$.

$(j>k)$, respectively, $i=1,2, \ldots, N$. The median of Sen's slope estimator is computed as

$$
Q_{\text {med }}= \begin{cases}Q_{[(N+1 / 2)]} & \text { if } N \text { is odd } \\ \frac{Q[N / 2]+Q[(N+2 / 2)]}{2} & \text { if } N \text { is even }\end{cases}
$$

The $Q_{\text {med }}$ sign reflects the data trend reflection, while its value represents the steepness of the trend [53]. A positive value of $Q_{i}$ means that there is an increasing trend, while a negative value of $Q_{i}$ indicates decreasing trend in the time series analysis.

\subsubsection{Serial Correlation Effect}

In a classical MK test, we assume that the observed time series data are serially independent. However, some significant autocorrelation coefficients may exist in the hydro-meteorological time series data $[3,43]$. The trend identified by the classical MK test would be increased (decreased) in a time series with positive (negative) autocorrelation coefficients. Generally, lag-1 autocorrelation is used to test for serial correlation in time series data [58]. The lag-1 autocorrelation coefficient is the simple correlation coefficient of the first observations $N-1, X_{t}, t=1,2,3, \ldots, N-1$ and the next observations, $X_{t+1}, t=2,3, \ldots, N$ [59]. The correlation between $X_{t}$ and $X_{t+1}$ is given as

$$
r_{1}=\frac{\sum_{t=1}^{N-1}\left(X_{t}-X\right)\left(X_{t+1}-\bar{X}\right)}{\sum_{t=1}^{N}\left(X_{t}-\bar{X}\right)^{2}}
$$

where $\bar{X}=\sum_{t=1}^{N} X_{t}$ is the overall mean.

Coefficient $r_{1}$ is tested for its significance. The probability limits on the correlogram of an independent series of the two tailed test is given below [59].

$$
r_{1}(95 \%)=\frac{-1 \pm \sqrt{N-k-1}}{N-k}
$$

where $N$ is the sample size and $k$ is the lag.

If the value of $r_{1}$ is outside the confidence interval given above, the data are assumed to be serially correlated otherwise the sample data are considered to be serially independent [59]. In this study, the autocorrelation function (ACF) plot implemented in Python was used to explore the significant autocorrelation coefficients with varying lagged values (confidence level of 0.05 ).

\subsubsection{The Revised Mann-Kendall Test}

In this study, the revised Mann-Kendall test (RMK) proposed by Hamed and Rao [47] was employed to address serial autocorrelation issues in rainfall time series analysis. This modified MK test uses a variance correction approach to improve trend analysis. All significant lags in time series 
data are considered in the RMK test. Detailed information and calculation methods can be found in previous research $[3,8]$.

\section{Results and Discussion}

\subsection{Statistical Characteristics of the Rainfall Time Series}

The basic monthly rainfall statistics of Shanxi province at 18 meteorological stations during the period from 1957 to 2019, such as the maximum, mean, standard deviation (SD), and coefficient of variation $(\mathrm{CV})$, were analyzed and presented in Table 2 . The maximum and mean of the long-term monthly rainfall at 18 meteorological stations in the study area varied from $264.70 \mathrm{~mm}$ to $468.60 \mathrm{~mm}$ and $31.93 \mathrm{~mm}$ to $64.27 \mathrm{~mm}$, respectively. The SD ranged from 38.45 to 70.03 and CV ranged from 109\% to $135 \%$, which indicates that there is a great temporal variation for the long-term monthly rainfall for the whole period of 63 years (1957-2019) in Shanxi province. The highest mean value was found at Wutai Shan station, whereas the CV here was lowest among the meteorological stations. These values indicate that the regions covered by Wutai Shan station with greater rainfall had less variability than the regions with relatively lower rainfall. This finding is consistent with the results of Gajbhiye et al. [4].

Table 2. Basic statistics of monthly rainfall at 18 meteorological stations during the period from 1957 to 2019.

\begin{tabular}{cccccc}
\hline Station & Min $(\mathbf{m m})$ & Max $(\mathbf{m m})$ & Mean $\mathbf{( m m})$ & SD & CV $\mathbf{( \% )}$ \\
\hline Youyu & 0 & 264.70 & 35.82 & 44.40 & 124 \\
Datong & 0 & 231.80 & 31.93 & 38.45 & 120 \\
Hequ & 0 & 339.40 & 34.74 & 46.74 & 135 \\
Wutai Shan & 0 & 403.10 & 64.27 & 70.03 & 109 \\
Wuzhai & 0 & 348.40 & 39.84 & 48.13 & 121 \\
Xingxian & 0 & 349.30 & 41.38 & 50.81 & 123 \\
Yuanping & 0 & 391.70 & 35.65 & 48.83 & 137 \\
Lishi & 0 & 321.90 & 41.44 & 51.85 & 125 \\
Taiyuan & 0 & 360.00 & 36.63 & 47.29 & 129 \\
Yangquan & 0 & 427.40 & 45.06 & 58.66 & 130 \\
Yushe & 0 & 351.60 & 45.16 & 55.96 & 124 \\
Xixian & 0 & 403.30 & 43.33 & 51.69 & 119 \\
Jiexiu & 0 & 298.90 & 38.48 & 47.05 & 122 \\
Linfen & 0 & 287.90 & 39.96 & 49.00 & 123 \\
Changzhi & 0 & 345.70 & 46.62 & 53.99 & 116 \\
Yuncheng & 0 & 287.40 & 43.91 & 48.10 & 110 \\
Houma & 0 & 305.90 & 42.48 & 48.82 & 115 \\
Yangcheng & 0 & 468.60 & 49.80 & 58.13 & 117 \\
\hline
\end{tabular}

SD means standard deviation; CV indicates coefficient of variation.

The basic statistics of seasonal (spring, summer, autumn, and winter) and annual rainfall in the study period of 1957-2019, such as the mean, SD, and CV, were also analyzed, and are shown in Table 3. The mean and SD of annual rainfall at different stations varied from $427.82 \mathrm{~mm}$ to $771.28 \mathrm{~mm}$ and from 84.27 to 205.95, respectively. There was a low CV at the annual scale, which indicates a less inter-annual variability with varied meteorological stations. In terms of seasonal rainfall, the mean and SD of spring rainfall varied from $59.90 \mathrm{~mm}$ to $125.12 \mathrm{~mm}$ and from 28.08 to 49.11 ; summer rainfall varied from $230.87 \mathrm{~mm}$ to $458.38 \mathrm{~mm}$ and from 68.92 to 145.90 ; autumn rainfall varied from $84.68 \mathrm{~mm}$ to $158.28 \mathrm{~mm}$ and from 36.50 to 75.58 ; and winter rainfall varied from $7.42 \mathrm{~mm}$ to $34.69 \mathrm{~mm}$ and from 4.5 to 22.44 over the period from 1957 to 2019. Summer had the highest mean rainfall and lowest CV, while winter had the lowest mean rainfall and highest CV. These findings indicate that the regions with greater rainfall have less variability than the regions with relatively lower rainfall. This finding is similar to the results of Gajbhiye et al. [4,11]. 
Table 3. Basic statistics of seasonal and annual rainfall at 18 meteorological stations during the period 1957 to 2019.

\begin{tabular}{|c|c|c|c|c|c|c|c|c|c|c|c|c|c|c|c|}
\hline \multirow{2}{*}{ Station } & \multicolumn{3}{|c|}{ Spring } & \multicolumn{3}{|c|}{ Summer } & \multicolumn{3}{|c|}{ Autumn } & \multicolumn{3}{|c|}{ Winter } & \multicolumn{3}{|c|}{ Annual } \\
\hline & Mean & SD & CV (\%) & Mean & SD & CV (\%) & Mean & SD & CV (\%) & Mean & SD & CV (\%) & Mean & SD & CV (\%) \\
\hline Youyu & 66.38 & 31.68 & 48 & 267.87 & 75.36 & 28 & 87.17 & 40.59 & 47 & 8.40 & 4.50 & 54 & 429.82 & 98.65 & 23 \\
\hline Datong & 59.90 & 28.20 & 47 & 230.87 & 68.92 & 30 & 84.68 & 36.50 & 43 & 7.68 & 4.84 & 63 & 383.13 & 84.27 & 22 \\
\hline Hequ & 60.71 & 30.30 & 50 & 258.56 & 101.23 & 39 & 88.63 & 43.76 & 49 & 9.03 & 5.61 & 62 & 416.93 & 127.93 & 31 \\
\hline Wutai Shan & 125.12 & 49.11 & 39 & 458.38 & 145.90 & 32 & 153.10 & 54.59 & 36 & 34.69 & 22.44 & 65 & 771.28 & 205.95 & 27 \\
\hline Wuzhai & 73.07 & 28.08 & 38 & 289.05 & 85.28 & 30 & 103.57 & 42.06 & 41 & 12.40 & 6.44 & 52 & 478.10 & 105.34 & 22 \\
\hline Xingxian & 73.91 & 29.85 & 40 & 293.12 & 102.59 & 35 & 115.99 & 50.19 & 43 & 13.56 & 7.27 & 54 & 496.58 & 129.82 & 26 \\
\hline Yuanping & 57.22 & 28.40 & 50 & 272.62 & 107.67 & 39 & 90.56 & 44.31 & 49 & 7.42 & 5.32 & 72 & 427.82 & 118.11 & 28 \\
\hline Lishi & 74.57 & 33.62 & 45 & 284.81 & 102.68 & 36 & 126.81 & 58.00 & 46 & 11.71 & 7.34 & 63 & 497.27 & 123.34 & 25 \\
\hline Taiyuan & 66.10 & 37.00 & 56 & 259.95 & 93.21 & 36 & 102.37 & 51.38 & 50 & 11.08 & 7.58 & 68 & 439.50 & 112.40 & 26 \\
\hline Yangquan & 79.81 & 43.94 & 55 & 334.03 & 117.84 & 35 & 113.08 & 53.73 & 48 & 13.84 & 9.57 & 69 & 540.76 & 143.37 & 27 \\
\hline Yushe & 76.98 & 34.30 & 45 & 328.15 & 108.20 & 33 & 121.13 & 53.19 & 44 & 15.67 & 9.16 & 58 & 541.94 & 123.64 & 23 \\
\hline Xixian & 81.33 & 38.25 & 47 & 290.86 & 99.78 & 34 & 132.18 & 61.40 & 46 & 15.59 & 9.30 & 60 & 519.96 & 123.47 & 24 \\
\hline Jiexiu & 73.94 & 34.22 & 46 & 259.40 & 88.56 & 34 & 115.60 & 55.33 & 48 & 12.81 & 7.83 & 61 & 461.75 & 108.35 & 23 \\
\hline Linfen & 82.56 & 38.08 & 46 & 262.40 & 97.39 & 37 & 121.33 & 59.00 & 49 & 13.29 & 8.67 & 65 & 479.58 & 113.68 & 24 \\
\hline Changzhi & 96.40 & 35.98 & 37 & 322.45 & 100.33 & 31 & 119.45 & 56.17 & 47 & 21.14 & 11.61 & 55 & 559.45 & 112.13 & 20 \\
\hline Yuncheng & 107.75 & 43.33 & 40 & 244.73 & 89.35 & 37 & 158.28 & 75.58 & 48 & 16.12 & 11.34 & 70 & 526.89 & 121.58 & 23 \\
\hline Houma & 99.45 & 43.58 & 44 & 253.20 & 99.08 & 39 & 137.76 & 60.23 & 44 & 19.36 & 12.02 & 62 & 509.77 & 121.57 & 24 \\
\hline Yangcheng & 107.22 & 42.13 & 39 & 321.91 & 115.45 & 36 & 143.93 & 65.82 & 46 & 24.57 & 15.26 & 62 & 597.62 & 134.60 & 23 \\
\hline
\end{tabular}




\subsection{Autocorrelation Analysis}

In this study, a total of 306 time series (each station contains 12 monthly, four seasonal, and one annual series) generated from 18 meteorological stations were employed to investigate the serial correlation by using the ACF plot in Python. The results of the ACF plot demonstrated that most of the observed series were serially independent. For instance, the time series of rainfall in March at Changzhi and Yuanping stations, in June at Xingxian station, and in September at Yangquan station show slight autocorrelation (Figure 2), which were not expected to influence the results of the trend analysis when using the MK test. Detailed information can be found in the following sections. Statistically significant autocorrelation coefficients were identified in February (first and third lags) and winter (first and second lags) at Wutai Shan station (Figure 3), which resulted in a disproportionate result using a classical MK test [60].
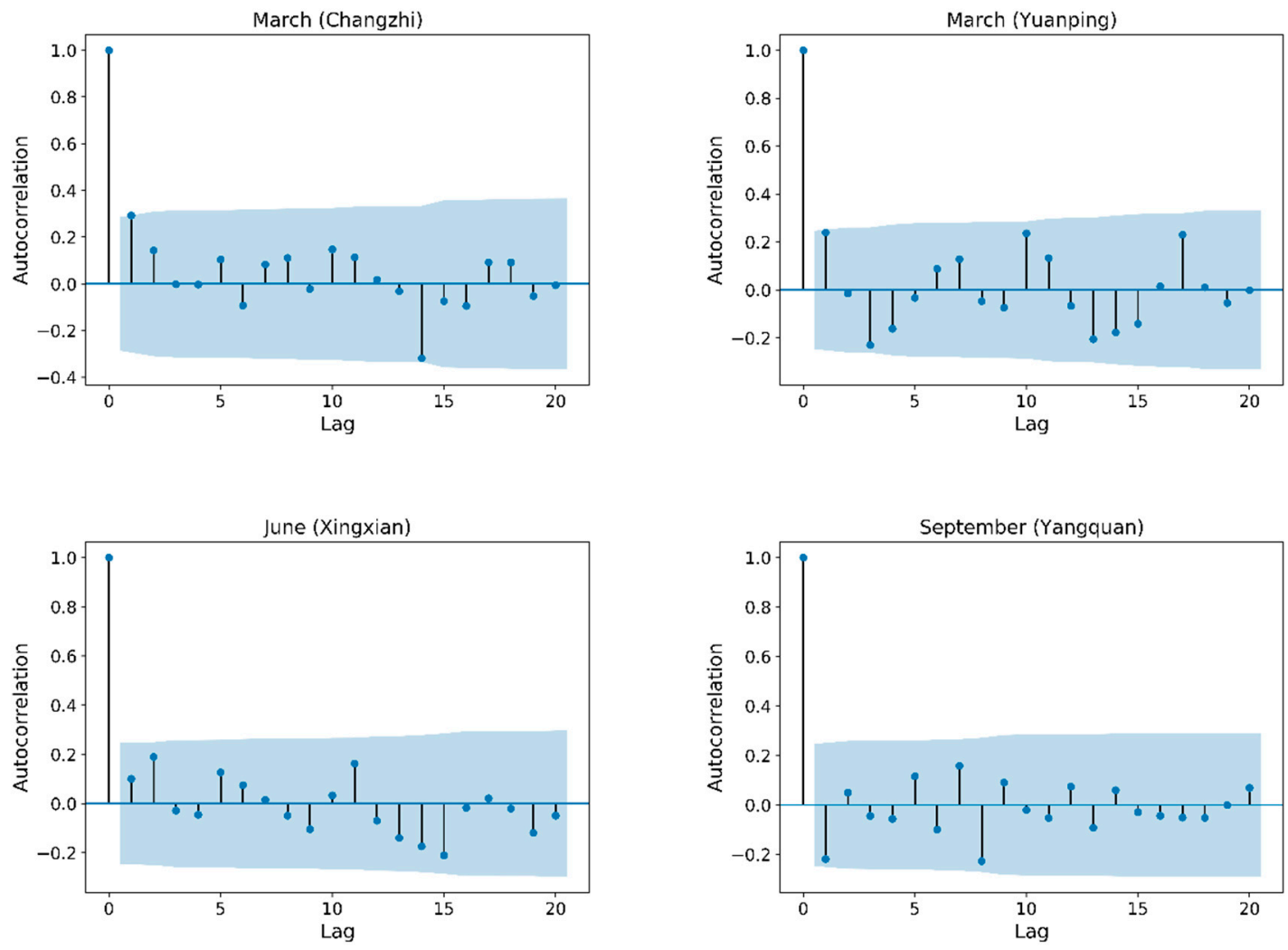

Figure 2. Autocorrelation Function (ACF) plot in March at Changzhi and Yuanping stations, in June at Xingxian station, and in September at Yangquan station.
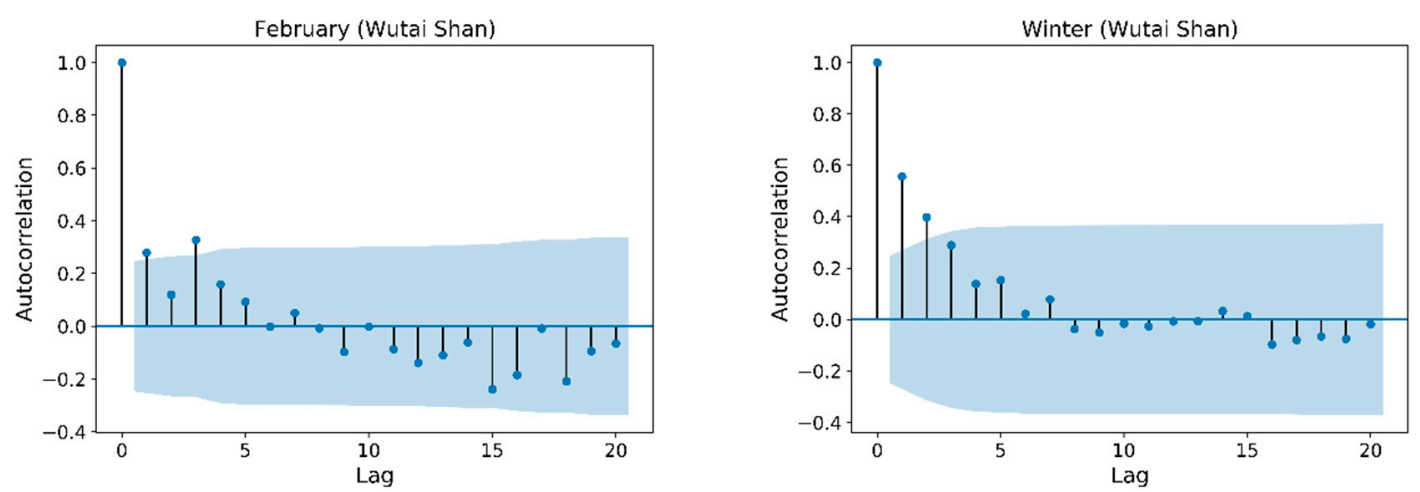

Figure 3. ACF plot in February and winter at Wutai Shan station. 


\subsection{Monthly, Seasonal, and Annual Rainfall Trend}

The results of the Mann-Kendall (MK) test and Spearman's Rho (SR) test without considering the effect of serial correlation for monthly rainfall series at each station in Shanxi province during the period from 1957 to 2019 are presented in Table 4. The significance level of 10\%, 5\%, and 1\% were considered at each station for Z-statistics of the MK and correlation coefficient of SR. Both positive and negative trends (either statistically significant or non-significant) depending on the stations, were identified using MK and SR tests for monthly rainfall series at 10\%, 5\%, and 1\% levels of significance. However, negative trends dominated at the monthly time scale. As can be seen from Table 4, there was no significant trend detected in June or September for all meteorological stations. Neither significant nor non-significant trends were detected at the monthly scale using the MK and SR tests at 10\%, 5\%, and 1\% significance levels at Youyu, Datong, Xingxian, Yuanping, Lishi, and Taiyuan stations. There was a significant increasing trend in May at Hequ and Wuzhai stations and a significant decreasing trend in March at Yuncheng and Yangcheng stations at the 10\% level using MK and SR, and a significant decreasing trend in March at Yushe and Chagnzhi at the 10\% level using MK and 5\% level using SR. The Wutai Shan station showed significant decreasing trends in January, February, March, April, November, and December at the $1 \%$ level using MK and SR. For the remaining months at Wutai Shan station, non-significant decreasing trends were identified by MK and SR (Table 4). Two stations, Wuzhai and Changzhi, experienced significant increasing trends in February at the 5\% level. Except for Yangquan and Yushe stations, neither significant positive nor negative trends were detected in August using the MK and SR tests. In July, only Yuncheng station experienced a significant decreasing trend at the $5 \%$ level, while the other stations showed non-significant decreasing trends. These finding are consistent with the findings of Gajbhiye et al. [4], which demonstrated that July in the Sindh Basin (1901-2002) experienced a decreasing trend (significant or non-significant at the 10\% level). The results of precipitation trends in Jiangxi province during 1960-2008 indicated that June, July, and August showed upward trends as detected by the MK test, which present a contrasting result compared with our study in Shanxi province [2]. The largest number of stations showing decreasing trends occurred in March with 10 out of 18 stations at the $10 \%, 5 \%$, and $1 \%$ levels. Overall, most stations experienced a decreasing trend (significant or non-significant) for the monthly rainfall series, as assessed using the MK and SR tests, during the period from 1957 to 2019, especially Wutai Shan station.

The results of the MK test and SR test, without considering the effect of serial correlation for seasonal and annual rainfall series at each station in Shanxi province over the period 1957-2019, are provided in Table 5. Across the four seasons, only Wutai Shan station showed significantly decreasing trends at the $10 \%, 5 \%$, and $1 \%$ levels; the other stations did not have significant trends. In summer, all stations exhibited decreasing trends, except Lishi, based on the MK and SR tests. Ye [61] investigated the trend of China's summer precipitation; they showed a significant increasing trend in south China and a decreasing trend in north China. However, no significant trends were identified in the west and China overall. The trend in summer in Shanxi province is consistent with that of north China. In autumn, non-significant upward trends were observed at most stations (13 stations). Trends in spring and winter depended on stations. On the annual scale, only Wutai Shan and Yangcheng stations showed significant decreasing trends at the $1 \%$ and $10 \%$ levels, respectively. Similarly, Sanikhani et al. [3] reported that most stations in central India during 1901-2010 had decreasing trends on an annual time scale. Sharma and Singh [59] also found that the annual rainfall series over the state of Jharkhand, India, experienced a significant downward trend with a decrease of $14.11 \%$. Wu and Qian [25] reported that annual rainfall shows a significant downward trend in the Wei River Basin and north of the Loess Plateau, where spring rainfall is the major contributor to the decline in annual rainfall. 
Table 4. Results of Mann-Kendall (MK) test and Spearman's Rho (SR) test without considering the effect of serial correlation for monthly rainfall series at 18 meteorological stations during the period from 1957 to 2019.

\begin{tabular}{|c|c|c|c|c|c|c|c|c|c|c|c|c|c|}
\hline Station & Test & Jan. & Feb. & Mar. & Apr. & May & June & July & Aug. & Sep. & Oct. & Nov. & Dec. \\
\hline \multirow{2}{*}{ Youyu } & MK & -1.106 & 1.181 & -0.795 & 0.605 & 1.418 & 0.243 & -1.269 & -1.103 & 0.540 & 0.771 & -0.475 & 0.916 \\
\hline & SR & -0.137 & 0.147 & -0.109 & 0.098 & 0.192 & 0.037 & -0.152 & -0.146 & 0.077 & 0.105 & -0.054 & 0.101 \\
\hline \multirow{2}{*}{ Datong } & MK & -1.500 & 0.944 & -0.676 & 0.475 & 1.026 & 1.596 & -1.026 & -1.180 & 1.180 & 0.664 & -0.184 & -0.312 \\
\hline & SR & -0.189 & 0.114 & -0.088 & 0.076 & 0.117 & 0.196 & -0.111 & -0.161 & 0.163 & 0.072 & -0.018 & -0.052 \\
\hline \multirow{2}{*}{ Hequ } & MK & -1.378 & 0.083 & -1.365 & -0.231 & 1.738 & 1.566 & -0.617 & -0.664 & 0.136 & -0.249 & -0.244 & -0.180 \\
\hline & SR & -0.187 & 0.028 & -0.185 & -0.026 & 0.248 & 0.211 & -0.074 & -0.088 & 0.016 & -0.021 & -0.026 & -0.023 \\
\hline \multirow[b]{2}{*}{ Wutai Shan } & MK & $-3.441^{* *}$ & -1.590 & $-3.547^{* *}$ & $-2.912 * *$ & -0.617 & -1.145 & -1.649 & -1.655 & -1.340 & -1.655 & -2.758 ** & $-3.797^{* *}$ \\
\hline & SR & $-0.422 * *$ & -0.199 & $-0.435^{* *}$ & $-0.377^{* *}$ & -0.077 & -0.162 & -0.213 & -0.219 & -0.155 & -0.163 & $-0.341^{* *}$ & $-0.474^{* *}$ \\
\hline \multirow{2}{*}{ Wuzhai } & MK & 0.160 & $2.053 *$ & -1.163 & 0.884 & 1.756 & 0.504 & -0.065 & 0.267 & 0.338 & 0.712 & -0.279 & -0.214 \\
\hline & SR & 0.034 & $0.262 *$ & -0.153 & 0.113 & 0.222 & 0.075 & -0.026 & 0.018 & 0.029 & 0.091 & -0.037 & -0.034 \\
\hline \multirow{2}{*}{ Xingxian } & MK & -0.766 & 0.071 & -1.346 & 0.184 & 1.192 & 1.418 & -0.813 & 0.089 & 0.077 & -1.068 & 0.018 & -0.125 \\
\hline & SR & -0.104 & 0.008 & -0.167 & 0.040 & 0.157 & 0.195 & -0.102 & 0.000 & -0.003 & -0.111 & 0.012 & -0.031 \\
\hline \multirow{2}{*}{ Yuanping } & MK & -0.904 & 0.226 & -0.059 & 0.937 & 1.429 & 1.157 & -0.474 & -0.854 & 0.338 & 0.142 & -0.791 & -0.348 \\
\hline & SR & -0.107 & 0.013 & -0.007 & 0.103 & 0.192 & 0.153 & -0.044 & -0.115 & 0.040 & 0.031 & -0.115 & -0.060 \\
\hline \multirow{2}{*}{ Lishi } & MK & -0.715 & 1.121 & -0.611 & 0.202 & 0.409 & 0.415 & -0.344 & 0.261 & 0.261 & -0.154 & -0.706 & 0.209 \\
\hline & SR & -0.107 & 0.134 & -0.075 & 0.030 & 0.043 & 0.068 & -0.023 & 0.025 & 0.039 & -0.013 & -0.084 & 0.026 \\
\hline \multirow{2}{*}{ Taiyuan } & MK & -0.814 & 0.552 & -1.341 & 0.154 & -0.065 & 0.510 & -0.593 & -0.071 & 0.741 & 0.261 & -1.283 & -0.043 \\
\hline & SR & -0.115 & 0.077 & -0.177 & 0.010 & -0.003 & 0.076 & -0.091 & -0.030 & 0.091 & 0.040 & -0.169 & -0.029 \\
\hline \multirow[b]{2}{*}{ Yangquan } & MK & -1.006 & -0.059 & $-2.177^{*}$ & 1.210 & 1.038 & 0.902 & -0.611 & $-2.260^{*}$ & 0.047 & 0.297 & -1.501 & -0.206 \\
\hline & SR & -0.129 & 0.002 & $-0.284^{*}$ & 0.141 & 0.149 & 0.133 & -0.089 & $-0.284^{*}$ & 0.008 & 0.038 & -0.181 & -0.043 \\
\hline \multirow{2}{*}{ Yushe } & MK & -0.530 & 0.718 & -1.940 & 0.718 & 0.872 & 0.896 & -1.062 & $-2.461^{* *}$ & 0.463 & -0.409 & -1.187 & 0.228 \\
\hline & SR & -0.070 & 0.078 & $-0.260^{*}$ & 0.090 & 0.134 & 0.139 & -0.119 & $-0.320^{*}$ & 0.052 & -0.050 & -0.148 & 0.014 \\
\hline \multirow[b]{2}{*}{ Xixian } & MK & -1.044 & 0.671 & $-2.581^{* *}$ & 0.297 & 0.374 & -0.795 & -1.619 & -0.599 & -0.243 & 0.047 & -1.205 & 0.168 \\
\hline & SR & -0.123 & 0.075 & $-0.309^{*}$ & 0.036 & 0.069 & -0.096 & -0.229 & -0.067 & -0.020 & 0.004 & -0.159 & 0.013 \\
\hline \multirow{2}{*}{ Jiexiu } & MK & 0.280 & 1.449 & -1.804 & 0.718 & -0.166 & -0.534 & -1.145 & 0.047 & 0.225 & -0.273 & -1.721 & -0.243 \\
\hline & SR & 0.043 & 0.184 & -0.238 & 0.094 & -0.010 & -0.073 & -0.132 & 0.013 & 0.049 & -0.026 & -0.198 & -0.043 \\
\hline \multirow[b]{2}{*}{ Linfen } & MK & -0.006 & 1.295 & $-2.058^{*}$ & 0.504 & 1.222 & 0.231 & -1.382 & -0.878 & 0.516 & -0.024 & -1.275 & 0.114 \\
\hline & SR & -0.003 & 0.163 & $-0.273^{*}$ & 0.059 & 0.175 & 0.011 & -0.175 & -0.115 & 0.056 & 0.002 & -0.167 & 0.019 \\
\hline \multirow{2}{*}{ Changzhi } & MK & 0.460 & $2.202 *$ & -1.816 & 1.339 & 1.623 & 0.807 & -0.220 & -1.229 & -0.275 & -0.440 & 0.761 & -0.175 \\
\hline & SR & 0.077 & $0.322 *$ & $-0.309 *$ & 0.189 & 0.253 & 0.116 & -0.028 & -0.195 & -0.032 & -0.071 & 0.112 & -0.026 \\
\hline \multirow{2}{*}{ Yuncheng } & MK & -0.536 & 1.460 & -1.821 & -0.736 & 0.071 & -0.095 & $-2.076^{*}$ & 0.166 & 0.053 & -0.047 & -1.299 & -0.533 \\
\hline & SR & -0.072 & 0.209 & -0.230 & -0.107 & 0.020 & -0.023 & -0.250 * & 0.034 & 0.006 & -0.010 & -0.159 & -0.081 \\
\hline \multirow{2}{*}{ Houma } & MK & 0.173 & 0.979 & $-2.325^{*}$ & 0.985 & 0.647 & 0.196 & -0.344 & -1.103 & 0.089 & 0.231 & -1.127 & -0.379 \\
\hline & SR & 0.029 & 0.119 & $-0.289 *$ & -0.137 & 0.104 & 0.027 & 0.051 & -0.133 & 0.025 & 0.013 & -0.156 & -0.049 \\
\hline \multirow{2}{*}{ Yangcheng } & MK & 0.030 & 1.537 & -1.869 & -0.320 & 0.937 & 0.136 & -1.382 & -1.441 & 0.172 & -0.113 & -1.240 & -0.892 \\
\hline & SR & 0.006 & 0.205 & -0.247 & -0.056 & 0.130 & 0.008 & -0.176 & -0.190 & 0.022 & -0.026 & -0.178 & -0.108 \\
\hline
\end{tabular}

Numbers in bold indicate significant values at the $10 \%$ level, ${ }^{*}$ Significant at the $5 \%$ level, ${ }^{* *}$ Significant at the $1 \%$ level. 
Table 5. Results of Mann-Kendall (MK) test and Spearman's Rho (SR) test without considering the effect of serial correlation for seasonal and annual rainfall series at 18 meteorological stations during the period from 1957 to 2019.

\begin{tabular}{|c|c|c|c|c|c|c|c|c|c|c|c|c|c|}
\hline Station & Test & Spring & Summer & Autumn & Winter & Annual & Station & Test & Spring & Summer & Autumn & Winter & Annual \\
\hline Youyu & $\begin{array}{l}\text { MK } \\
\text { SR }\end{array}$ & $\begin{array}{l}1.269 \\
0.208\end{array}$ & $\begin{array}{l}-1.162 \\
-0.151\end{array}$ & $\begin{array}{l}1.085 \\
0.134\end{array}$ & $\begin{array}{l}0.338 \\
0.054\end{array}$ & $\begin{array}{l}0.261 \\
0.038\end{array}$ & Yangquan & $\begin{array}{l}\text { MK } \\
\text { SR }\end{array}$ & $\begin{array}{l}0.516 \\
0.083\end{array}$ & $\begin{array}{l}-1.447 \\
-0.189\end{array}$ & $\begin{array}{l}0.083 \\
0.005\end{array}$ & $\begin{array}{l}-1.032 \\
-0.124\end{array}$ & $\begin{array}{l}-1.168 \\
-0.166\end{array}$ \\
\hline Datong & $\begin{array}{c}\text { MK } \\
\text { SR }\end{array}$ & $\begin{array}{l}0.955 \\
0.114\end{array}$ & $\begin{array}{l}-0.985 \\
-0.106\end{array}$ & $\begin{array}{l}1.317 \\
0.183\end{array}$ & $\begin{array}{l}-0.528 \\
-0.07\end{array}$ & $\begin{array}{l}0.783 \\
0.072\end{array}$ & Yushe & $\begin{array}{c}\text { MK } \\
\text { SR }\end{array}$ & $\begin{array}{l}0.824 \\
0.108\end{array}$ & $\begin{array}{c}-1.412 \\
-0.19\end{array}$ & $\begin{array}{l}0.125 \\
0.003\end{array}$ & $\begin{array}{c}0.19 \\
0.024\end{array}$ & $\begin{array}{l}-1.506 \\
-0.204\end{array}$ \\
\hline Hequ & $\begin{array}{l}\text { MK } \\
\text { SR }\end{array}$ & $\begin{array}{l}1.038 \\
0.138\end{array}$ & $\begin{array}{l}-0.635 \\
-0.063\end{array}$ & $\begin{array}{l}0.522 \\
0.069\end{array}$ & $\begin{array}{l}-0.997 \\
-0.128\end{array}$ & $\begin{array}{l}-0.178 \\
-0.027 \\
\end{array}$ & Xixian & $\begin{array}{l}\text { MK } \\
\text { SR }\end{array}$ & $\begin{array}{l}-0.225 \\
-0.036 \\
\end{array}$ & $\begin{array}{c}-1.4 \\
-0.196\end{array}$ & $\begin{array}{l}-0.154 \\
-0.015\end{array}$ & $\begin{array}{l}-0.356 \\
-0.042 \\
\end{array}$ & $\begin{array}{l}-1.578 \\
-0.204 \\
\end{array}$ \\
\hline Wutai Shan & $\begin{array}{l}\text { MK } \\
\text { SR }\end{array}$ & $\begin{array}{l}-3.203^{* *} \\
-0.405^{* *}\end{array}$ & $\begin{array}{l}-2.372^{* *} \\
-0.301 *\end{array}$ & $\begin{array}{l}-1.827 \\
-0.232\end{array}$ & $\begin{array}{c}-3.47^{* *} \\
-0.465^{* *}\end{array}$ & $\begin{array}{l}-3.369^{* *} \\
-0.439^{* *}\end{array}$ & Jiexiu & $\begin{array}{c}\text { MK } \\
\text { SR }\end{array}$ & $\begin{array}{c}-0.35 \\
-0.038\end{array}$ & $\begin{array}{c}-0.51 \\
-0.065\end{array}$ & $\begin{array}{l}0.095 \\
0.012\end{array}$ & $\begin{array}{l}0.652 \\
0.106 \\
\end{array}$ & $\begin{array}{l}-0.694 \\
-0.091\end{array}$ \\
\hline Wuzhai & $\begin{array}{l}\text { MK } \\
\text { SR }\end{array}$ & $\begin{array}{l}1.435 \\
0.181\end{array}$ & $\begin{array}{l}-0.136 \\
-0.026\end{array}$ & $\begin{array}{l}1.684 \\
0.193\end{array}$ & $\begin{array}{l}1.103 \\
0.139\end{array}$ & $\begin{array}{l}0.700 \\
0.088\end{array}$ & Linfen & $\begin{array}{l}\text { MK } \\
\text { SR }\end{array}$ & $\begin{array}{l}0.641 \\
0.081\end{array}$ & $\begin{array}{l}-0.866 \\
-0.118\end{array}$ & $\begin{array}{l}-0.249 \\
-0.025\end{array}$ & $\begin{array}{l}0.641 \\
0.094\end{array}$ & $\begin{array}{l}-1.269 \\
-0.164\end{array}$ \\
\hline Xingxian & $\begin{array}{l}\text { MK } \\
\text { SR }\end{array}$ & $\begin{array}{l}0.813 \\
0.092\end{array}$ & $\begin{array}{l}-0.231 \\
-0.026\end{array}$ & $\begin{array}{c}0.32 \\
0.038\end{array}$ & $\begin{array}{l}-0.475 \\
-0.061\end{array}$ & $\begin{array}{l}0.415 \\
0.042\end{array}$ & hangzhi & $\begin{array}{l}\text { MK } \\
\text { SR }\end{array}$ & $\begin{array}{l}1.266 \\
0.182\end{array}$ & $\begin{array}{l}-0.514 \\
-0.055\end{array}$ & $\begin{array}{c}0.028 \\
-0.005\end{array}$ & $\begin{array}{l}1.036 \\
0.165\end{array}$ & $\begin{array}{l}0.037 \\
0.024\end{array}$ \\
\hline Yuanping & $\begin{array}{l}\text { MK } \\
\text { SR }\end{array}$ & $\begin{array}{l}1.566 \\
0.167\end{array}$ & $\begin{array}{l}-0.356 \\
-0.049 \\
\end{array}$ & $\begin{array}{l}0.819 \\
0.095\end{array}$ & $\begin{array}{l}-0.386 \\
-0.041\end{array}$ & $\begin{array}{c}0.059 \\
-0.006\end{array}$ & Yuncheng & $\begin{array}{l}\text { MK } \\
\text { SR }\end{array}$ & $\begin{array}{l}-1.376 \\
-0.18\end{array}$ & $\begin{array}{c}-1.56 \\
-0.208\end{array}$ & $\begin{array}{l}-0.225 \\
-0.033\end{array}$ & $\begin{array}{l}0.32 \\
0.05\end{array}$ & $\begin{array}{c}\mathbf{- 1 . 7 5} \\
-0.226 \\
\end{array}$ \\
\hline Lishi & $\begin{array}{l}\text { MK } \\
\text { SR }\end{array}$ & $\begin{array}{l}-0.119 \\
-0.026\end{array}$ & $\begin{array}{l}0.231 \\
0.028\end{array}$ & $\begin{array}{l}0.676 \\
0.076\end{array}$ & $\begin{array}{c}0.166 \\
0.02\end{array}$ & $\begin{array}{c}0.083 \\
-0.004\end{array}$ & Houma & $\begin{array}{l}\text { MK } \\
\text { SR }\end{array}$ & $\begin{array}{l}-0.824 \\
-0.109\end{array}$ & $\begin{array}{l}-0.985 \\
-0.112\end{array}$ & $\begin{array}{c}0.142 \\
0.01\end{array}$ & $\begin{array}{l}0.765 \\
0.118\end{array}$ & $\begin{array}{l}-1.032 \\
-0.129\end{array}$ \\
\hline Taiyuan & $\begin{array}{l}\text { MK } \\
\text { SR }\end{array}$ & $\begin{array}{l}-0.273 \\
-0.036\end{array}$ & $\begin{array}{c}-0.13 \\
-0.034\end{array}$ & $\begin{array}{l}0.617 \\
0.088\end{array}$ & $\begin{array}{l}-0.219 \\
-0.025\end{array}$ & $\begin{array}{l}-0.629 \\
-0.083\end{array}$ & Yangcheng & $\begin{array}{l}\text { MK } \\
\text { SR }\end{array}$ & $\begin{array}{l}-0.083 \\
-0.012\end{array}$ & $\begin{array}{c}-1.85 \\
-0.227\end{array}$ & $\begin{array}{l}-0.457 \\
-0.065\end{array}$ & $\begin{array}{l}0.783 \\
0.099\end{array}$ & $\begin{array}{l}-1.779 \\
-0.213\end{array}$ \\
\hline
\end{tabular}

Numbers in bold indicate significant values at the $10 \%$ level, * Significant at the $5 \%$ level, ${ }^{* *}$ Significant at the $1 \%$ level. 
From the trend analysis of the monthly, seasonal, and annual rainfall series above, we can conclude that MK and SR have similar power for detecting the trend of rainfall time series data. This result agrees with the finding of Yue et al. [55]. They demonstrated that these two tests have similar power in detecting monotonic trends in hydrological series.

The Revised Mann-Kendall (RMK) test was used to improve the trend analysis by considering the autocorrelation effect on rainfall time series data over the period of 1957-2019. The results of the RMK test for monthly rainfall series at each station are shown in Table 6. The number of significant trends for all stations have changed when using the RMK instead of the MK test. For instance, the Z-statistic value of Wutai Shan station in February and Datong station in June changed from -1.590 (MK) to $-1.722(\mathrm{RMK})$ and from $1.596(\mathrm{MK})$ to 1.724 (RMK), respectively, which indicates that there is a significant trend at a significance level of $10 \%$ when using the RMK test. This is mainly contributed to the variance correction method for eliminating the effect of autocorrelation in rainfall time series. February at Wuzhai station showed a significant upward trend at level of 5\% based on MK result, while the Z-statistic value of the RMK test indicated a significant increasing trend at the level of $1 \%$. The Yuncheng station in July experienced a similar change; the Z-statistic value changed from -2.076 (MK test at significance level of 5\%) to -2.974 (RMK test at a significance level of $1 \%$ ). In addition, the values of the Z-statistic in August at Yushe station, in July at Xixian station, and in December at Hequ and Houma stations also changed when using the RMK instead of the MK test. This indicates that decreasing trends occurred more frequently in March, while increasing trends occurred more often in February (Tables 4 and 6).

The results of the RMK test, considering the effect of serial correlation for seasonal and annual rainfall series over the period of 1957-2019 are shown in Table 7. The trend in winter at Wutai Shan station was decreasing at a significance level of $5 \%$ when considering the serial correlation effect using the RMK test, while the MK test presented a downward trend at the level of $1 \%$. The values of the Z-statistic based on MK test were $-1.376,-1.56$, and -1.75 , for spring, summer, and annual at Yuncheng station, respectively, while the values of Z-statistic using RMK test were $-2.301,-2.285$, and -2.391, respectively (Tables 5 and 7). On the seasonal scale, summer for all stations showed a decreasing trend (significant or non-significant). There was no significant trend at the annual scale, except for Wutai Shan, Yushe, Yuncheng, and Yangcheng stations.

It should be noted that the Z-statistic value of Hequ station in December changed dramatically from -0.18 (MK) to -4.289 (RMK; Table 6). In winter, Jiexiu station presented an unreasonable Z-statistic value (10.179) when using the RMK test, which is not consistent with actual trend of the rainfall time series in winter (Table 7). The $\operatorname{Var}(s)$ of MK in December at Hequn station and in winter at Jiexiu station was 27,813.667 and 28,423, respectively, while the RMK was only 48.92 and 116.79, respectively. Although similar trends and slopes obtained from monthly, seasonal, and annual rainfall series in Shanxi province over the period 1957-2019 were found using RMK test, mismatched results were also generated. Therefore, the RMK test may not be suitable for detecting monotonic trend in some cases. More trend identification methods should be considered, as suggested by Patakamuri et al. [52], to obtain accurate trend in hydro-meteorological variables. 
Table 6. Results of the Revised Mann-Kendall (RMK) test with considering the effect of serial correlation for monthly rainfall series at 18 meteorological stations during the period from 1957 to 2019.

\begin{tabular}{|c|c|c|c|c|c|c|c|c|c|c|c|c|}
\hline Station & Jan & Feb. & Mar. & Apr. & May & June & July & Aug. & Sep. & Oct. & Nov. & Dec. \\
\hline Youyu & -1.106 & 1.181 & -0.671 & 0.823 & 1.328 & 0.343 & -1.180 & -1.103 & 0.700 & 0.669 & -1.306 & 0.916 \\
\hline Datong & -1.500 & 0.944 & -0.586 & 0.517 & 1.026 & 1.724 & -1.258 & -1.403 & 1.180 & 0.664 & -0.223 & -0.365 \\
\hline Hequ & -1.442 & 0.083 & -1.866 & -0.231 & 1.253 & 1.566 & -0.617 & -1.040 & 0.141 & -0.249 & -0.344 & $-4.289 * *$ \\
\hline Wutai Shan & $-4.407^{* *}$ & -1.722 & $-4.691 * *$ & $-2.912 * *$ & -0.750 & -1.145 & -1.649 & -1.546 & -1.340 & -1.655 & $-3.805^{* *}$ & $-3.058 * *$ \\
\hline Wuzhai & 0.226 & $5.761 * *$ & -1.163 & 1.476 & 1.756 & 0.496 & -0.065 & 0.279 & 0.338 & 0.712 & -0.324 & -0.253 \\
\hline Xingxian & -0.766 & 0.071 & -1.346 & 0.163 & 1.011 & 1.636 & -0.813 & 0.094 & 0.077 & -1.068 & 0.025 & -0.159 \\
\hline Yuanping & -0.904 & 0.226 & -0.138 & 0.937 & 1.164 & 1.356 & -0.474 & -0.854 & 0.338 & 0.142 & -0.741 & -0.775 \\
\hline Lishi & -0.715 & 1.121 & -0.611 & 0.202 & 0.702 & 0.588 & -0.344 & 0.261 & 0.297 & -0.154 & -0.752 & 0.537 \\
\hline Taiyuan & -0.814 & 0.552 & -1.341 & 0.194 & -0.077 & 0.994 & -0.593 & -0.071 & 0.741 & 0.261 & -1.480 & -0.069 \\
\hline Yangquan & -1.402 & -0.059 & $-2.841 * *$ & 1.210 & 1.038 & 0.286 & -0.671 & $-2.260 *$ & 0.047 & 0.297 & -1.672 & -0.220 \\
\hline Yushe & -0.530 & 0.718 & $-2.840 * *$ & 0.872 & 0.872 & 1.189 & -1.062 & $-2.133^{*}$ & 0.463 & -0.409 & -1.480 & 0.653 \\
\hline Xixian & -1.044 & 0.671 & $-2.581 * *$ & 0.297 & 0.470 & -1.470 & -1.925 & -0.768 & -0.243 & 0.047 & -1.345 & 0.330 \\
\hline Jiexiu & 0.280 & 1.449 & -1.804 & 0.718 & -0.166 & -0.534 & -1.145 & 0.047 & 0.225 & -0.383 & -1.606 & -0.873 \\
\hline Linfen & -0.006 & 1.295 & $-4.164 * *$ & 0.504 & 1.222 & 0.289 & -1.382 & -0.878 & 0.389 & -0.024 & -1.185 & 0.408 \\
\hline Changzhi & 0.460 & $2.160 *$ & $-2.144 *$ & 1.837 & 1.467 & 0.807 & -0.273 & -1.229 & -0.275 & -0.383 & 0.729 & -0.197 \\
\hline Yuncheng & -0.517 & 1.460 & $-2.319 *$ & -0.967 & 0.071 & -0.107 & $-2.974 * *$ & 0.166 & 0.053 & -0.047 & -1.494 & -1.136 \\
\hline Houma & 0.173 & 0.761 & $-2.325^{*}$ & -0.985 & 0.604 & 0.196 & -0.300 & -0.990 & 0.094 & 0.308 & -0.956 & -1.829 \\
\hline Yangcheng & 0.030 & 1.537 & -1.869 & -0.221 & 1.048 & 0.177 & -1.382 & -1.624 & 0.146 & -0.113 & -1.192 & -0.892 \\
\hline
\end{tabular}

Numbers in bold indicate significant values at the $10 \%$ level, * Significant at the $5 \%$ level, ${ }^{* *}$ Significant at the $1 \%$ level.

Table 7. Results of the Revised Mann-Kendall (RMK) test with considering the effect of serial correlation for seasonal and annual rainfall series at 18 meteorological stations during the period from 1957 to 2019.

\begin{tabular}{cccccccccccc}
\hline Station & Spring & Summer & Autumn & Winter & Annual & Station & Spring & Summer & Autumn & Winter & Annual \\
\hline Youyu & 1.269 & $-\mathbf{1 . 8 9 2}$ & 1.085 & 0.338 & 0.23 & Yangquan & 0.516 & -1.447 & 0.069 & -1.285 & -1.168 \\
Datong & 0.955 & -1.16 & 1.317 & -0.528 & 0.959 & Yushe & 0.824 & -1.412 & 0.125 & 0.356 & $\mathbf{- 1 . 6 9 2}$ \\
Hequ & 1.038 & -0.635 & 0.522 & -0.997 & -0.178 & Xixian & -0.225 & -1.378 & -0.154 & -0.498 & -1.578 \\
Wutai Shan & $-3.203^{* *}$ & $-2.372^{* *}$ & $\mathbf{- 1 . 8 2 7}$ & $-2.011^{*}$ & $-3.369^{* *}$ & Jiexiu & -0.415 & -0.51 & 0.093 & $10.179^{* *}$ & -0.694 \\
Wuzhai & 1.435 & -0.136 & $\mathbf{1 . 6 8 4}$ & $2.565 * *$ & 0.700 & Linfen & 0.872 & -0.866 & -0.249 & 0.833 & -1.269 \\
Xingxian & 0.813 & -0.231 & 0.32 & -0.577 & 0.415 & Changzhi & 1.266 & -0.514 & 0.028 & 1.036 & 0.037 \\
Yuanping & $\mathbf{1 . 7 8 6}$ & -0.392 & 0.819 & -0.386 & 0.059 & Yuncheng & $-2.301^{*}$ & $-2.285^{*}$ & -0.225 & 0.759 & $-2.391 * *$ \\
Lishi & -0.113 & 0.252 & 0.481 & 0.28 & 0.091 & Houma & -1.543 & -0.985 & 0.142 & 0.804 & -1.032 \\
Taiyuan & -0.25 & -0.192 & 0.454 & -0.219 & -0.925 & Yangcheng & -0.093 & $\mathbf{- 1 . 8 5}$ & -0.457 & $\mathbf{1 . 9 0 4}$ & $\mathbf{- 1 . 7 7 9}$ \\
\hline
\end{tabular}

Numbers in bold indicate significant values at the $10 \%$ level, ${ }^{*}$ Significant at the $5 \%$ level, ** Significant at the $1 \%$ level. 
As indicated by the above analysis, early spring (March) experienced a decreasing (significant or non-significant) trend at most stations. This indicated that the climate of Shanxi province will be drier in the future. March is the beginning of spring plowing in Shanxi province, so a negative influence on agricultural activities, the water supply, the natural environment, public health, and socioeconomic development can be expected. Stations with significant decreasing trends at the $10 \%, 5 \%$, and $1 \%$ level are mainly distributed in the east, south, and south-east of Shanxi province. In the north-east of Shanxi province, only Wutai Shan station showed a significant decreasing trend at the $1 \%$ level in March. However, stations distributed in the west and north-west of Shanxi province presented non-significant decreasing trends. Therefore, adaptation pathways for changes of rainfall in Shanxi province should be formulated based on the sensitive regions and time period, such as optimizing the planting structure, building agricultural irrigation projects, and constructing water conservancy projects, and these should be flexible in order to respond to future knowledge of climate change to guards against the potential risks $[62,63]$.

\subsection{Magnitude of Trend}

The magnitudes of the trends for the monthly, seasonal, and annual rainfall series over the period from 1957 to 2019 in the study area were calculated using Sen's slope estimator, and are provided in Table 8. In January, 6 out of 18 stations had no trend, while other stations had slight negative slopes (close to zero). Most of stations in February showed a positive slope or no trend, except Wutai Shan station $(-0.104 \mathrm{~mm} /$ year), while all stations in March presented a negative slope, especially Wutai Shan station ( $-0.494 \mathrm{~mm} /$ year). There was an increasing slope of the rainfall trend in the monthly series (April to June, September) for most stations. The values of Sen's slope in Table 8 indicate that the falling slope of the rainfall trend existed in July, August, October, and November. There was no significant trend slope identified in December. A negative trend of rainfall slope was observed for all stations in summer. This finding is not consistent with the results of Gajbhiye et al. [4], who concluded that all stations in the Sindh River Basin in India had positive trend slope for the summer season. Huang et al. [2] applied the MK test to detect rainfall trends at the monthly, seasonal, and annual scale during 1960-2008 in Jiangxi province, south-east China. They found that significant increasing trends existed in January, August, winter, and summer. 
Table 8. The magnitudes of trend slope for monthly, seasonal, and annual rainfall time series at each station over the period from 1957 to 2019.

\begin{tabular}{|c|c|c|c|c|c|c|c|c|c|c|c|c|c|c|c|c|c|}
\hline Station & Jan. & Feb. & Mar. & Apr. & May & June & July & Aug. & Sep. & Oct. & Nov. & Dec. & Spring & Summer & Autumn & Winter & Annual \\
\hline Youyu & -0.010 & 0.025 & -0.030 & 0.057 & 0.194 & 0.050 & -0.421 & -0.464 & 0.131 & 0.100 & -0.008 & 0.005 & 0.241 & -0.617 & 0.335 & 0.012 & 0.152 \\
\hline Datong & -0.010 & 0.017 & -0.022 & 0.048 & 0.118 & 0.229 & -0.326 & -0.322 & 0.268 & 0.064 & 0.000 & 0.000 & 0.159 & -0.594 & 0.388 & -0.017 & 0.539 \\
\hline Hequ & -0.011 & 0.000 & -0.067 & -0.030 & 0.254 & 0.282 & -0.312 & -0.296 & 0.035 & -0.029 & 0.000 & 0.000 & 0.182 & -0.573 & 0.185 & -0.044 & -0.214 \\
\hline Wutaishan & -0.135 & -0.104 & -0.494 & -0.420 & -0.109 & -0.312 & -0.963 & -1.040 & -0.429 & -0.279 & -0.333 & -0.180 & -1.067 & -2.263 & -0.740 & -0.428 & -4.224 \\
\hline Wuzhai & 0.000 & 0.062 & -0.053 & 0.094 & 0.241 & 0.083 & -0.028 & 0.120 & 0.083 & 0.059 & -0.017 & -0.003 & 0.294 & -0.080 & 0.467 & 0.056 & 0.485 \\
\hline Xingxian & -0.011 & 0.000 & -0.071 & 0.030 & 0.204 & 0.345 & -0.351 & 0.071 & 0.029 & -0.133 & 0.000 & 0.000 & 0.155 & -0.157 & 0.126 & -0.025 & 0.439 \\
\hline Yuanping & 0.000 & 0.000 & 0.000 & 0.091 & 0.220 & 0.236 & -0.190 & -0.430 & 0.107 & 0.013 & -0.028 & 0.000 & 0.348 & -0.238 & 0.238 & -0.013 & 0.035 \\
\hline Lishi & -0.007 & 0.029 & -0.043 & 0.027 & 0.068 & 0.065 & -0.160 & 0.072 & 0.069 & -0.021 & -0.054 & 0.000 & -0.019 & 0.179 & 0.258 & 0.007 & 0.075 \\
\hline Taiyuan & -0.002 & 0.011 & -0.066 & 0.026 & -0.009 & 0.133 & -0.277 & -0.011 & 0.203 & 0.032 & -0.059 & 0.000 & -0.071 & -0.066 & 0.200 & -0.009 & -0.461 \\
\hline Yangquan & -0.012 & 0.000 & -0.119 & 0.142 & 0.193 & 0.205 & -0.352 & -0.921 & 0.016 & 0.043 & -0.084 & 0.000 & 0.132 & -1.236 & 0.029 & -0.050 & -1.227 \\
\hline Yushe & -0.003 & 0.023 & -0.114 & 0.103 & 0.150 & 0.226 & -0.493 & -1.103 & 0.127 & -0.054 & -0.083 & 0.000 & 0.200 & -1.173 & 0.038 & 0.016 & -1.205 \\
\hline Xixian & -0.012 & 0.018 & -0.180 & 0.036 & 0.066 & -0.175 & -0.693 & -0.281 & -0.089 & 0.006 & -0.085 & 0.000 & -0.071 & -1.067 & -0.096 & -0.020 & -1.659 \\
\hline Jiexiu & 0.000 & 0.042 & -0.112 & 0.093 & -0.033 & -0.074 & -0.450 & 0.011 & 0.068 & -0.042 & -0.107 & 0.000 & -0.087 & -0.323 & 0.052 & 0.050 & -0.500 \\
\hline Linfen & 0.000 & 0.038 & -0.147 & 0.071 & 0.226 & 0.050 & -0.606 & -0.333 & 0.148 & -0.005 & -0.090 & 0.000 & 0.136 & -0.640 & -0.094 & 0.036 & -1.083 \\
\hline Changzhi & 0.010 & 0.170 & -0.207 & 0.246 & 0.564 & 0.419 & -0.150 & -0.577 & -0.124 & -0.100 & 0.077 & 0.000 & 0.500 & -0.450 & 0.020 & 0.129 & 0.093 \\
\hline Yuncheng & -0.003 & 0.056 & -0.159 & -0.112 & 0.013 & -0.022 & -0.850 & 0.067 & 0.028 & -0.009 & -0.144 & 0.000 & -0.365 & -0.987 & -0.105 & 0.024 & -1.433 \\
\hline Houma & 0.000 & 0.041 & -0.221 & -0.146 & 0.109 & 0.044 & -0.176 & -0.417 & 0.032 & 0.062 & -0.114 & 0.000 & -0.237 & -0.586 & 0.041 & 0.052 & -0.878 \\
\hline Yangcheng & 0.000 & 0.097 & -0.157 & -0.037 & 0.179 & 0.047 & -0.800 & -0.576 & 0.055 & -0.028 & -0.138 & -0.004 & -0.015 & -1.586 & -0.225 & 0.078 & -1.718 \\
\hline
\end{tabular}




\subsection{Impacts of ENSO on Rainfall in Shanxi Province}

Previous studies have demonstrated that atmospheric circulation patterns (e.g., ENSO) have an influence on global and regional precipitation [64-70]. In order to better understand the impacts of extreme climate events on rainfall in Shanxi province, seasonal and annual rainfall anomalies in the years of El Niño and La Niña were analyzed based on the average rainfall over the period of 1981-2010. As indicated by the National Oceanic and Atmospheric Administration (NOAA), El Niño and La Niña events can be identified by using Oceanic Niño Index (ONI), which is the running 3-month mean sea surface temperature (SST) anomaly for the Niño 3.4 region. According to the results of ONI, very strong El Niño patterns occurred in 1982-1983, 1997-1998 and 2015-2016, strong El Niño patterns presented in 1957-1958, 1965-1966, 1972-1973, 1987-1988, and 1991-1992, and strong La Niña patterns were observed in 1973-1974, 1975-1976, 1988-1989, 1998-1999, 1999-2000, 2007-2008 and 2010-2011 (https://ggweather.com/enso/oni.htm). Rainfall anomalies in seasonal and annual rainfall in the specific El Niño and La Niña years were calculated and are presented in Table 9. As it can be seen from Table 9, both El Niño and La Niña have different degrees of impacts on rainfall. In general, negative annual rainfall anomalies occurred in El Niño years (e.g., 1997, 2015, 1957, 1965, 1972, 1987, and 1991), while positive annual rainfall anomalies presented in La Niña years, excluding 1974, 1999, 2000, 2008, and 2010. From the analysis of ENSO and annual rainfall anomalies, rainfall showed a reduction in El Niño years, and is mainly increased in La Niña years. This is consistent with the statistical analysis of Li et al. [71], which showed that there are many years with reduced annual precipitation in El Niño years, and the probability of negative anomalies is $58.8 \%$, while many years with increased annual precipitation were La Niña years, with a probability of positive anomalies of $56.5 \%$. However, annual rainfall increased in other El Niño years (Table 9), which is in line with results of Li et al. [71].

Table 9. Rainfall anomaly in seasonal and annual rainfall based on the average rainfall during the period (1981-2010).

\begin{tabular}{|c|c|c|c|c|c|}
\hline \multirow{2}{*}{$\begin{array}{l}\text { Very Strong El } \\
\text { Niño }\end{array}$} & \multicolumn{5}{|c|}{ Rainfall Anomaly } \\
\hline & Spring & Summer & Autumn & Winter & Annual \\
\hline 1982 & -11.03 & 49.79 & -14.12 & -1.14 & 23.50 \\
\hline 1983 & 58.57 & -38.97 & 58.46 & -8.52 & 69.53 \\
\hline 1997 & -11.11 & -125.70 & -23.65 & -2.07 & -162.53 \\
\hline 1998 & 54.56 & 13.06 & -62.31 & -3.45 & 1.86 \\
\hline 2015 & -0.87 & -94.14 & 62.54 & 6.51 & -25.96 \\
\hline 2016 & 0.83 & 96.02 & 17.32 & 4.50 & 118.66 \\
\hline \multirow{2}{*}{ Strong El Niño } & \multicolumn{5}{|c|}{ Rainfall anomaly } \\
\hline & Spring & Summer & Autumn & Winter & Annual \\
\hline 1957 & 5.8551 & -6.6057 & -50.835 & 5.1837 & -46.402 \\
\hline 1958 & 31.237 & 134.694 & 9.359 & 5.0073 & 180.298 \\
\hline 1965 & 2.8963 & -115.08 & -51.294 & -7.557 & -171.04 \\
\hline 1966 & -7.621 & 149.406 & -24.753 & -3.057 & 113.975 \\
\hline 1972 & -44.92 & -93.712 & -14.294 & 9.9367 & -142.99 \\
\hline 1973 & -24.3 & 115.241 & 55.03 & -3.269 & 142.698 \\
\hline 1987 & 7.7786 & -13.012 & 2.1708 & -3.31 & -6.3725 \\
\hline 1988 & 10.667 & 175.177 & -50.812 & -2.481 & 132.551 \\
\hline 1991 & 60.902 & -102.66 & -18.2 & 4.1484 & -55.814 \\
\hline 1992 & -2.715 & 36.859 & -1.0527 & -11.73 & 21.3627 \\
\hline \multirow{2}{*}{ Strong La Niña } & \multicolumn{5}{|c|}{ Rainfall anomaly } \\
\hline & Spring & Summer & Autumn & Winter & Annual \\
\hline 1973 & -24.3 & 115.241 & 55.03 & -3.269 & 142.698 \\
\hline 1974 & -24.19 & -60.335 & 8.8531 & 10.095 & -65.573 \\
\hline 1975 & -14.58 & 8.9002 & 44.83 & 0.2367 & 39.3863 \\
\hline 1976 & -9.833 & 86.4355 & -4.3763 & 14.554 & 86.7804 \\
\hline 1988 & 10.667 & 175.177 & -50.812 & -2.481 & 132.551 \\
\hline 1989 & -23.6 & 23.459 & 2.7237 & 13.86 & 16.4451 \\
\hline 1998 & 54.555 & 13.059 & -62.312 & -3.446 & 1.85686 \\
\hline 1999 & -6.457 & -73.617 & -9.3763 & -12.35 & -101.8 \\
\hline 2000 & -42.15 & 5.27078 & 8.7649 & 1.672 & -26.443 \\
\hline 2007 & 6.161 & 26.1237 & 32.347 & 2.0014 & 66.6333 \\
\hline 2008 & 10.949 & -40.906 & 13.3 & 0.4778 & -16.178 \\
\hline 2010 & 6.0316 & -30.706 & 0.5884 & -2.181 & -26.267 \\
\hline 2011 & -15.12 & -4.9469 & 88.065 & 1.1955 & 69.198 \\
\hline
\end{tabular}


On the seasonal scale, generally, summer rainfall decreased in most El Niño years (e.g., 1957, 1965, 1972, 1987, 1991, 1997 and 2015), while summer rainfall increased in most La Niña years (e.g., 1973, 1975, 1976, 1988, 1998 and 2007) and the following El Niño years (e.g., 1958, 1966, 1973, 1988, 1992, 1998 and 2016). Overall, different intensities of ENSO events have positive and negative impacts on seasonal and annual precipitation in Shanxi province, and the direction of the increase or decrease is uncertain. However, the response of annual precipitation to El Niño years is mainly decreased, while it is increased in the following El Niño years. For La Niña years, increases are typically seen. Summer rainfall responds significantly to El Niño and La Niña years.

\section{Conclusions}

In this study, the trends and magnitudes of slope for monthly, seasonal, and annual rainfall series at 18 meteorological stations in Shanxi province during the period from 1957 to 2019 were investigated using three trend identification methods (MK/SR and RMK tests) and Sen's slope estimator. Both positive and negative trends (significant or non-significant at the significance levels of $10 \%, 5 \%$, and $1 \%$ ), depending on stations, were identified in the study area. Similar trends are generally obtained for monthly, seasonal, and annual rainfall series from the MK/SR and RMK tests. In some cases, however, there were some unreasonable results (e.g., monthly rainfall in December at Hequn station and seasonal rainfall in winter at Jiexiu station) provided by the RMK test instead of the MK/SR test. The main findings of this study are summarized as follows.

1. The months June and September showed no significant trends for all stations according to the MK/SR, while only September showed no significant trend using the RMK test. March experienced significant decreasing trends for most stations (Wutai shan, Yangquan, Yushe, Xixian, Jiexiu, Linfen, Changzhi, Yuncheng, Houma, and Yangcheng) at the significance levels of $10 \%, 5 \%$, and $1 \%$ identified by the MK/SR and RMK tests. Only Wutai Shan station showed a significant downward trend in January, March, April, November, and December at the levels of $1 \%$ and $5 \%$ by the application of the MK/SR and RMK tests. For remaining stations, significant increasing or decreasing trends were observed in February (Wuzhai and Changzhi), April (Changzhi), May (Wuzhai), June (Datong), July (Xixian and Yuncheng), August (Yangquan and Yushe), and December (Houma).

2. On the seasonal scale, similar results were obtained by using the MK/SR and RMK tests. However, the number of significant trends was increased by the application of RMK test. The values of the Z-statistic in summer at Youyu, Yuncheng, and Yangcheng stations using the RMK test showed a significant decreasing trend at the level of $10 \%$, while those using the MK/SR test showed no significant trends. In addition, spring, summer and winter at Yuanping, Yuncheng, and Yangcheng, experienced similar changes when using the RMK test instead of the MK/SR test. Over the four seasons, both the MK/SR and RMK tests indicated that Wutai Shan station showed a significant decreasing trend at a significance level of 1\% (spring, summer, and winter) and $10 \%$ (autumn). On the annual scale, most stations showed non-significant trends, except Wutai Shan, Yushe, Yuncheng, and Yangcheng, with the application of the RMK test.

3. Summer showed a negative slope magnitudes for all stations. The Wutai Shan station showed the highest negative slope magnitude in the annual series $(-4.224 \mathrm{~mm} /$ year $)$, followed by the summer $(-2.263 \mathrm{~mm} /$ year $)$. Spring ranked third, with a decreasing rate of $-1.067 \mathrm{~mm} /$ year. The magnitudes of the trend slope in January, February, and December for all stations were no trend or slightly increasing (decreasing; close to zero). A falling slope of the rainfall trend existed in July, August, October, and November.

4. Both MK and SR have similar power for detecting monotonic trend in rainfall time series data. Overall, the RMK test proposed by Hamed and Rao [38] can improve the trend analysis of rainfall series by considering the autocorrelation effect at significant lags. 
Author Contributions: F.G. conceived and designed the framework of this study; F.G. processed the data and analyzed the results; F.G. wrote the paper; Y.W., X.C., and W.Y. reviewed and edited the manuscript and resources for publishing the article. All authors have read and agreed to the published version of the manuscript.

Funding: This research was funded by the National Key Research and Development Program (Grant No.2018YFC1506506), Shanxi Province Applied Basic Research Program (Grant No. 201901D211407), Open Research Fund Program of LIESMARS (Grant No. 19R04), Shanxi Provincial Key Lab of Resources, Environment and Disaster Monitoring (Grant No. 2019-05), Scientific and Technological Innovation Programs of Higher Education Institutions in Shanxi (Grant No. 2019L0485), the key Research and Development Projects of Shanxi Province (Grant No. 201803D31224), and the Shanxi Provincial Key Lab of Resources, Environment and Disaster Monitoring (Grant No. 201805D111014).

Acknowledgments: We are thankful to the China Meteorological Data Network for rainfall data support. We would like to thank the two anonymous reviewers for their constructive comments.

Conflicts of Interest: The authors declare no conflict of interest.

\section{References}

1. Huang, J.; Sun, S.; Xue, Y.; Zhang, J. Spatial and temporal variability of precipitation indices during 1961-2010 in Hunan province, central south China. Theor. Appl. Climatol. 2014, 118, 581-595. [CrossRef]

2. Huang, J.; Sun, S.; Zhang, J. Detection of trends in precipitation during 1960-2008 in Jiangxi province, southeast China. Theor. Appl. Climatol. 2013, 114, 237-251. [CrossRef]

3. Sanikhani, H.; Kisi, O.; Mirabbasi, R.; Meshram, S.G. Trend analysis of rainfall pattern over the central India during 1901-2010. Arabian J. Geosci. 2018, 11, 437. [CrossRef]

4. Gajbhiye, S.; Meshram, C.; Mirabbasi, R.; Sharma, S.K. Trend analysis of rainfall time series for Sindh river basin in India. Theor. Appl. Clim. 2015, 125, 593-608. [CrossRef]

5. Warwade, P.; Tiwari, S.; Ranjan, S.; Chandniha, S.K.; Adamowski, J. Spatio-temporal variation of rainfall over Bihar State, India. J. Water Land Dev. 2018, 36, 183-197. [CrossRef]

6. Huang, J.; Zhang, J.; Zhang, Z.; Xu, C.-Y. Spatial and temporal variations in rainfall erosivity during 1960-2005 in the Yangtze river basin. Stoch. Environ. Res. Risk Assess. 2012, 27, 337-351. [CrossRef]

7. De Luis, M.; González-Hidalgo, J.C.; Brunetti, M.; Longares, L.A. Precipitation concentration changes in Spain 1946-2005. Nat. Hazards Earth Syst. Sci. 2011, 11, 1259-1265. [CrossRef]

8. Malik, A.; Kumar, A. Spatio-temporal trend analysis of rainfall using parametric and non-parametric tests: Case study in Uttarakhand, India. Theor. Appl. Clim. 2020, 140, 183-207. [CrossRef]

9. Almazroui, M.; Islam, M.N.; Athar, H.; Jones, P.D.; Rahman, M.A. Recent climate change in the Arabian Peninsula: Annual rainfall and temperature analysis of Saudi Arabia for 1978-2009. Int. J. Clim. 2012, 32, 953-966. [CrossRef]

10. Raj, P.P.N.; Azeez, P.A. Trend analysis of rainfall in Bharathapuzha River basin, Kerala, India. Int. J. Clim. 2011, 32, 533-539. [CrossRef]

11. Gajbhiye, S.; Meshram, C.; Singh, S.K.; Srivastava, P.K.; Islam, T. Precipitation trend analysis of Sindh River basin, India, from 102-year record (1901-2002). Atmos. Sci. Lett. 2015, 17, 71-77. [CrossRef]

12. Sivajothi, R.; Karthikeyan, K. Long-Term Trend Analysis of Changing Precipitation in Tamil Nadu, India. Int. J. Eng. Technol. 2018, 7, 980-984. [CrossRef]

13. Chandniha, S.K.; Meshram, S.G.; Adamowski, J.F.; Meshram, C. Trend analysis of precipitation in Jharkhand State, India. Theor. Appl. Clim. 2016, 130, 261-274. [CrossRef]

14. Altava-Ortiz, V.; Llasat, M.-C.; Ferrari, E.; Atencia, A.; Sirangelo, B. Monthly rainfall changes in Central and Western Mediterranean basins, at the end of the 20th and beginning of the 21st centuries. Int. J. Clim. 2010, 31, 1943-1958. [CrossRef]

15. Bartolini, G.; Grifoni, D.; Magno, R.; Torrigiani, T.; Gozzini, B. Changes in temporal distribution of precipitation in a Mediterranean area (Tuscany, Italy) 1955-2013. Int. J. Clim. 2017, 38, 1366-1374. [CrossRef]

16. Bartolini, G.; Grifoni, D.; Torrigiani, T.; Vallorani, R.; Meneguzzo, F.; Gozzini, B. Precipitation changes from two long-term hourly datasets in Tuscany, Italy. Int. J. Clim. 2014, 34, 3977-3985. [CrossRef]

17. Brunetti, M.; Caloiero, T.; Coscarelli, R.; Gullà, G.; Nanni, T.; Simolo, C. Precipitation variability and change in the Calabria region (Italy) from a high resolution daily dataset. Int. J. Clim. 2010, 32, 57-73. [CrossRef]

18. Caloiero, T.; Coscarelli, R.; Ferrari, E.; Mancini, M. Trend detection of annual and seasonal rainfall in Calabria (Southern Italy). Int. J. Clim. 2010, 31, 44-56. [CrossRef] 
19. Birara, H.; Pandey, R.P.; Mishra, S.K. Trend and variability analysis of rainfall and temperature in the Tana basin region, Ethiopia. J. Water Clim. Chang. 2018, 9, 555-569. [CrossRef]

20. Chang, X.; Xu, Z.; Zhao, G.; Cheng, T.; Song, S. Spatial and temporal variations of precipitation during 1979-2015 in Jinan city, China. J. Water Clim. Chang. 2018, 9, 540-554. [CrossRef]

21. Duan, A.; Wang, M.; Lei, Y.; Cui, Y. Trends in summer rainfall over china associated with the Tibetan Plateau sensible heat source during 1980-2008. J. Clim. 2013, 26, 261-275. [CrossRef]

22. Shi, P.; Qiao, X.; Chen, X.; Zhou, M.; Qu, S.; Ma, X.; Zhang, Z. Spatial distribution and temporal trends in daily and monthly precipitation concentration indices in the upper reaches of the Huai River, China. Stoch. Environ. Res. Risk Assess. 2013, 28, 201-212. [CrossRef]

23. Shi, P.; Wu, M.; Qu, S.; Jiang, P.; Qiao, X.; Chen, X.; Zhou, M.; Zhang, Z. Spatial Distribution and Temporal Trends in Precipitation Concentration Indices for the Southwest China. Water Resour. Manag. 2015, 29, 3941-3955. [CrossRef]

24. Wang, Y.; Xu, Y.; Tabari, H.; Wang, J.; Wang, Q.; Song, S.; Hu, Z. Innovative trend analysis of annual and seasonal rainfall in the Yangtze River Delta, eastern China. Atmos. Res. 2020, 231, 104673. [CrossRef]

25. Wu, H.; Qian, H. Innovative trend analysis of annual and seasonal rainfall and extreme values in Shaanxi, China, since the 1950s. Int. J. Clim. 2016, 37, 2582-2592. [CrossRef]

26. Daniels, E.E.; Lenderink, G.; Hutjes, R.W.A.; Holtslag, A.A.M. Spatial precipitation patterns and trends in The Netherlands during 1951-2009. Int. J. Clim. 2013, 34, 1773-1784. [CrossRef]

27. Park, J.-S.; Kang, H.-S.; Lee, Y.S.; Kim, M.-K. Changes in the extreme daily rainfall in South Korea. Int. J. Clim. 2010, 31, 2290-2299. [CrossRef]

28. Fernandes, L.G.; Rodrigues, R.R. Changes in the patterns of extreme rainfall events in southern Brazil. Int. J. Clim. 2017, 38, 1337-1352. [CrossRef]

29. Duan, Z.; Chen, Q.; Chen, C.; Liu, J.; Gao, H.; Song, X.; Wei, M. Spatiotemporal analysis of nonlinear trends in precipitation over Germany during 1951-2013 from multiple observation-based gridded products. Int. J. Climatol. 2018, 39, 2120-2135. [CrossRef]

30. Druyan, L.M. Studies of 21st-century precipitation trends over West Africa. Int. J. Clim. 2010, 31, 1415-1424. [CrossRef]

31. Zhang, C.; Wang, Z.; Zhou, B.; Li, Y.; Tang, H.; Xiang, B. Trends in autumn rain of West China from 1961 to 2014. Theor. Appl. Clim. 2018, 135, 533-544. [CrossRef]

32. Zhang, Q.; Singh, V.P.; Li, J.; Jiang, F.; Bai, Y. Spatio-temporal variations of precipitation extremes in Xinjiang, China. J. Hydrol. 2012, 434, 7-18. [CrossRef]

33. Qiang, Z.; Singh, V.P.; Peng, J.; Chen, Y.D.; Li, J. Spatial-temporal changes of precipitation structure across the Pearl River basin, China. J. Hydrol. 2012, 440, 113-122. [CrossRef]

34. Yang, H.-L.; Xiao, H.; Guo, C.; Sun, Y. Spatial-temporal analysis of precipitation variability in Qinghai Province, China. Atmos. Res. 2019, 228, 242-260. [CrossRef]

35. Zhang, Q.; Xu, C.; Zhang, Z.; Chen, X.; Han, Z. Precipitation extremes in a karst region: A case study in the Guizhou province, southwest China. Theor. Appl. Clim. 2009, 101, 53-65. [CrossRef]

36. Zhang, Q.; Xu, C.-Y.; Zhang, Z.; Chen, Y.D.; Liu, C.-L. Spatial and temporal variability of precipitation over China, 1951-2005. Theor. Appl. Clim. 2008, 95, 53-68. [CrossRef]

37. Liu, Q.; Yang, Z.; Cui, B. Spatial and temporal variability of annual precipitation during 1961-2006 in Yellow River basin, China. J. Hydrol. 2008, 361, 330-338. [CrossRef]

38. Li, X.; Wang, X.; Babovic, V. Analysis of variability and trends of precipitation extremes in Singapore during 1980-2013. Int. J. Clim. 2017, 38, 125-141. [CrossRef]

39. Chow, W.T. The impact of weather extremes on urban resilience to hydro-climate hazards: A Singapore case study. Int. J. Water Resour. Dev. 2017, 34, 510-524. [CrossRef]

40. Guo, X.; Wu, Z.-F.; He, H.S.; Du, H.; Wang, L.; Yang, Y.; Zhao, W. Variations in the start, end, and length of extreme precipitation period across China. Int. J. Clim. 2017, 38, 2423-2434. [CrossRef]

41. Lü, M.; Wu, S.-J.; Chen, J.; Chen, C.; Wen, Z.; Huang, Y. Changes in extreme precipitation in the Yangtze River basin and its association with global mean temperature and ENSO. Int. J. Clim. 2017, 38, 1989-2005. [CrossRef]

42. Ii, M.Q.V.; Matsumoto, J.; Kubota, H.; Villafuerte, M.Q. Changes in extreme rainfall in the Philippines (1911-2010) linked to global mean temperature and ENSO. Int. J. Clim. 2014, 35, 2033-2044. [CrossRef] 
43. Tedeschi, R.G.; Grimm, A.M.; Cavalcanti, I.F.A. Influence of Central and East ENSO on extreme events of precipitation in South America during austral spring and summer. Int. J. Clim. 2014, 35, 2045-2064. [CrossRef]

44. Dai, A.; Wigley, T.M.L. Global patterns of ENSO-induced precipitation. Geophys. Res. Lett. 2000, 27, 1283-1286. [CrossRef]

45. Philippon, N.; Rouault, M.; Richard, Y.; Favre, A. The influence of ENSO on winter rainfall in South Africa. Int. J. Clim. 2011, 32, 2333-2347. [CrossRef]

46. Räsänen, T.A.; Kummu, M. Spatiotemporal influences of ENSO on precipitation and flood pulse in the Mekong River Basin. J. Hydrol. 2013, 476, 154-168. [CrossRef]

47. Hamed, K.H.; Rao, A.R. A modified Mann-Kendall trend test for autocorrelated data. J. Hydrol. 1998, 204, 182-196. [CrossRef]

48. Zhao, G.X.; Zhao, C.P.; Li, X.S. Analysis of climate change in Shanxi Province in recent 47 years. Arid Zone Res. 2006, 23, 500-503. (In Chinese)

49. Yang, Q.; Liu, D.F.; Meng, X.M. Spatial and temporal variation characteristics of precipitation and temperature in Shanxi Province from 1960 to 2017. Pearl River 2019, 40, 27-33. (In Chinese)

50. Mann, H.B. Nonparametric Tests against Trend. Econometrica 1945, 13, 245. [CrossRef]

51. Kendall, M.G. Rank Correlation Methods; Charles Griffin: London, UK, 1955.

52. Patakamuri, S.K.; Muthiah, K.; Sridhar, V. Long-Term Homogeneity, Trend, and Change-Point Analysis of Rainfall in the Arid District of Ananthapuramu, Andhra Pradesh State, India. Water 2020, 12, 211. [CrossRef]

53. Gocic, M.; Trajkovic, S. Analysis of changes in meteorological variables using Mann-Kendall and Sen's slope estimator statistical tests in Serbia. Global Planet. Chang. 2013, 100, 172-182. [CrossRef]

54. Spearman, C. The Proof and Measurement of Association between Two Things. Am. J. Psychol. 1904, 15, 72. [CrossRef]

55. Yue, S.; Pilon, P.; Cavadias, G. Power of the Mann-Kendall and Spearman's rho tests for detecting monotonic trends in hydrological series. J. Hydrol. 2002, 259, 254-271. [CrossRef]

56. Theil, H. A Rank-Invariant Method of Linear and Polynomial Regression Analysis. Adv. Stud. Theor. Appl. Econom. 1992, 23, 345-381. [CrossRef]

57. Sen, P.K. Estimates of the Regression Coefficient Based on Kendall's Tau. J. Am. Stat. Assoc. 1968, 63, 1379-1389. [CrossRef]

58. Anderson, R.L. Distribution of the Serial Correlation Coefficient. Ann. Math. Stat. 1942, 13, 1-13. [CrossRef]

59. Sharma, S.; Singh, P.K. Long Term Spatiotemporal Variability in Rainfall Trends over the State of Jharkhand, India. Climate 2017, 5, 18. [CrossRef]

60. Yue, S.; Pilon, P.; Phinney, B.; Cavadias, G. The influence of autocorrelation on the ability to detect trend in hydrological series. Hydrol. Process. 2002, 16, 1807-1829. [CrossRef]

61. Ye, J.-S. Trend and variability of China's summer precipitation during 1955-2008. Int. J. Climatol. 2014, 34, 559-566. [CrossRef]

62. Li, X.; Zhang, K.; Babovic, V. Projections of Future Climate Change in Singapore Based on a Multi-Site Multivariate Downscaling Approach. Water 2019, 11, 2300. [CrossRef]

63. Manocha, N.; Babovic, V. Development and valuation of adaptation pathways for storm water management infrastructure. Environ. Sci. Policy 2017, 77, 86-97. [CrossRef]

64. Qiang, Z.; Li, J.; Singh, V.P.; Xu, C.; Deng, J. Influence of ENSO on precipitation in the East River basin, south China. J. Geophys. Res. Atmos. 2013, 118, 2207-2219. [CrossRef]

65. Xiao, M.; Qiang, Z.; Singh, V.P. Spatiotemporal variations of extreme precipitation regimes during 1961-2010 and possible teleconnections with climate indices across China. Int. J. Clim. 2016, 37, 468-479. [CrossRef]

66. Mariotti, A. How ENSO impacts precipitation in southwest central Asia. Geophys. Res. Lett. 2007, $34,34$. [CrossRef]

67. Xu, Z.X.; Takeuchi, K.; Ishidaira, H. Correlation between El Niño-Southern Oscillation(ENSO) and precipitation in South-east Asia and the Pacific region. Hydrol. Process. 2004, 18, 107-123. [CrossRef]

68. Yeo, S.-R.; Yeh, S.; Kim, Y.; Yim, S.-Y. Monthly climate variation over Korea in relation to the two types of ENSO evolution. Int. J. Clim. 2017, 38, 811-824. [CrossRef]

69. Yeh, S.; Kim, H.; Kwon, M.; Dewitte, B. Changes in the spatial structure of strong and moderate El Niño events under global warming. Int. J. Clim. 2013, 34, 2834-2840. [CrossRef] 
70. Wang, H.; Asefa, T. Impact of different types of ENSO conditions on seasonal precipitation and streamflow in the Southeastern United States. Int. J. Clim. 2017, 38, 1438-1451. [CrossRef]

71. Li, F.; Zhang, J.X.; Hao, Z.W.; Wu, Y.L.; Zhou, J.H. Correlation analysis of rainfall and ENSO in Shanxi. Acta Geogr. Sin. 2015, 70, 420-430.

(c) (

(C) 2020 by the authors. Licensee MDPI, Basel, Switzerland. This article is an open access article distributed under the terms and conditions of the Creative Commons Attribution (CC BY) license (http://creativecommons.org/licenses/by/4.0/). 